\title{
Teaching Practical Theology: Introducing Six Perspectives
}

Kathleen Cahalan, Carol Lakey Hess, and Bonnie Miller-McLemore

In the United States, practical theology has long been the discipline within the theological education curriculum that defines the sub-disciplines and courses in ministry. Typically, these sub-disciplines have included homiletics, liturgics, religious education and formation, pastoral care, church administration, and social mission. In the $1980 \mathrm{~s}$, this understanding of practical theology was deemed too narrow and parochial and scholars moved to advance broader and less clerical understandings of practical theology, though they did not reject the notion that practical theology still pertains to these functions of religious leadership. As broader understandings of practical theology became widely accepted, however, few practical theologians took up the question of how practical theology shapes the ministry curriculum as a whole or how it defines the various sub-disciplines that make up the curriculum and relates them to each other.

In April 2006, the Association of Practical Theology (APT) in the United States hosted its biennial meeting at Vanderbilt University under the title, "Practical Theology and Its Sub-Disciplines: Pedagogies and Their Implications for Practical Theology." Through a series of discussions focused on pedagogy, presenters and participants explored the distinctive and particular character of each sub-discipline as well as what they hold in common. For the sake of time and focus we limited our discussion to six areas (education, worship, pastoral care, homiletics, administration, and mission), with the recognition that areas such as formation, spirituality, congregational studies, and contextual education would all need to be addressed in future APT meetings. Beyond the general question about how practical theologians teach in each area, the presenters and participants explored the following questions:

- What are the distinctive pedagogies in each of the sub-disciplines that define practical theology?

- What are some of the most challenging pedagogical problems that we face teaching in each sub-discipline?

- Through an examination of the particular pedagogies of each subdiscipline, what do all, or most, have in common with the other subdisciplines? 
- How can we begin to define the relationship of the sub-disciplines to each other?

- In considering these relationships or lack thereof, how do we understand the way in which each sub-discipline interfaces with practical theology as a fundamental discipline in its own right?

- What does our examination of the sub-disciplines mean for our definitions of practical theology?

- What implications can be drawn from these reflections about how practical theology can relate to the theological curriculum as a whole (including biblical studies, history, systematic theology, ethics, religion and society) and the more personal, integrative disciplines of spiritual and professional formation for ministry?

On behalf of APT, we want to express our gratitude to the International Journal of Practical Theology for publishing the six presentations from the 2006 biennial meeting. We also want to thank the authors for revising their presentations for publication. We believe the issues raised about the teaching of practical theology have merit for our colleagues around the world and we hope this stimulates a larger conversation on pedagogies in practical theology. 
Distinctive Pedagogies in Religious Education

\section{Katherine Turpin}

I begin my reflections on pedagogies in religious education as a teacher with four years of full-time teaching, so my experience cannot be taken as representative for the field. In order to supplement my own experience, I have gathered from several other sources of evidence in order to claim what is distinctive about religious education pedagogy. First, I have begun by reflecting on my own teaching practice, which includes team teaching with others in the discipline and conversations with others in the discipline about our teaching practice. Team teaching with colleagues in other disciplines has also taught me that I sometimes approach the teaching task in quite distinctive ways from them, and this has also been instructive about the pedagogical norms within my own field. Finally, I have reviewed close to twenty syllabi from religious education colleagues to examine how they organize their courses, which gives some sense of how they teach the course. From my reflection on this data, I have identified seven clusters of goals characteristic to the pedagogy of religious education. After elaborating on each goal, I will conclude with a brief discussion of two teaching challenges particular to the field of religious education.

\section{Teaching about Teaching by Teaching}

People in religious education "teach about teaching by teaching," or better, we educate about religious education by educating. Many religious education syllabi will note that, "students can expect to participate in the establishment of a learning community," often coupled with the virtues that the professor hopes that community will possess. The first characteristic pedagogy of religious education is modeling through the teaching of the course. My classroom is also the laboratory for my discipline. Religious educators are blessed and burdened by the knowledge that everything we do in the classroom, from how we establish the learning environment to how we help the class negotiate conflict among learners with diverse experiences and perspectives, ${ }^{1}$ is teaching about good practices of religious education.

Religious educators often attempt to model many different approaches to the practice of education in the ways they teach their classes. This includes engaging students in different modes or forms of learning, such as cognitive, affective, social, experiential, and spiritual. In addition, professors model various strategies for engaging a topic: presentation (such as a

1 The struggle of teachers to address productive conflict in multicultural pedagogy is discussed in: bell hooks, Teaching to Transgress. Education as the Practice of Freedom, New York (Routledge) 1994, 35-44. 
lecture on the history of a particular practice), small group discussion and reporting out to a large groups, use of the arts as a form of inquiry and reflection (role plays, dramatic performance, simulation games, writing exercise, visual representation, and music), drawing on multiple intelligences in approaching materials, etc. ${ }^{2}$ An example of this can be found in Ted Brelsford's syllabus for a course entitled "Creativity and Pedagogy":

Exposure to, use of, and reflection on various forms of human creative expression (music, poetry, writing, visual arts, dance, drama) will be woven through the course. We will experience these in direct and intentional ways, and seek to learn through our engagement with them. ${ }^{3}$

As evidenced in this example, a professor often teaches a particular model or approach by actually leading the class through that approach, often engaging in metanarrative that analyzes the experience and how it affects student learning.

Teaching through the practice of teaching bears some similarity to the work of our pastoral care colleagues in the classroom. For example, one colleague in pastoral care notes that it matters little what you teach about empathetic listening if you fail to model empathetic listening when your students speak in class. The actions in the classroom serve as an example for students to imitate in their own practice and are reinforced by articulation or naming of the skills and approaches as they are engaged.

\section{Increasing Student Repertoire of Models of Religious Educational Practice}

A second distinctive pedagogy in religious education is exposure to multiple models and approaches to religious educational practice. Professors introduce a breadth of approaches in order to expand the possibilities of good practice. This introduction is particularly important because students often have an understanding of the practice of religious education limited to their own exposure to Sunday School or Bible study classes in a local community of faith. Exposure to multiple models provides a base of knowledge of fundamentals upon which the student can draw as they create their own practice. Having access to key approaches is like learning scales so that one can begin to improvise in a particular key.

The increasing of a student repertoire of models and approaches usually happens through fairly traditional means. Students will read about models through exploring the literature of the field. Faculty may also

2 Eight clusters of common pedagogies utilized in the practice of religious education and that could be modeled in the teaching of religious education are detailed in: Norma Cook Everist, The Church as Learning Community. A Comprehensive Guide to Christian Education, Nashville (Abingdon) 2002, 103-148.

3 www.candler.emory.edu/ABOUT/faculty/TBRELSF/syllabus_revised.pdf (January 2 2008). 
present historical trends and approaches to the practice in lecture format. As noted earlier, professors may also introduce the models through experiential forms of engagement in the models in the classroom and later reflection upon the experience. The goal of this exposure is to expand the student's imagination about how one might engage in the practice through exploring a few key approaches, such as intergenerational models, ${ }^{4}$ faith development models, ${ }^{5}$ practice-based approaches, ${ }^{6}$ event-centered education, ${ }^{7}$ liturgical formation/catechesis, ${ }^{8}$ shared Christian praxis, ${ }^{9}$ aesthetic education, ${ }^{10}$ and story-linking models. ${ }^{11}$

Classes frequently engage in some element of these models in order to gain firsthand experience. As a part of introducing the concept of liturgical formation, for instance, I have my introductory religious education class engage in a prayer postures exercise. We move the desks to the sides of the classroom and put our bodies in the center of the room as we experiment with one prayer posture after another. After a few minutes of holding the posture, we reflect on what each posture communicates about the "location" of God, the relationship of members of the community to one another, and the emotive tone of the praying moment. We then reflect on the embedded theological understandings communicated in particular contexts through the positioning of bodies during prayer, and how this is but one element of an entire education that happens in ritual moment. ${ }^{12}$ This kind of experiential learning is important in getting a real sense of what happens in the models and how they work. The goal

4 Anne E. Streaty Wimberly/Evelyn Parker, eds., In Search of Wisdom. Faith Formation in the Black Church, Nashville (Abingdon) 2002; James W. White, Intergenerational Religious Education. Models, Theory, and Prescription for Interage Life and Learning in the Faith Community, Birmingham, Ala. (Religious Education Press) 1988.

5 James W. Fowler, Stages of Faith. The Psychology of Human Development and the Quest for Meaning, San Francisco (HarperSanFrancisco) 1981; James W. Fowler, Becoming Adult, Becoming Christian, San Francisco (Jossey Bass) 2000.

6 Craig Dykstra, Growing in the Life of Faith. Education and Christian Practices, Louisville (Geneva) 1999.

7 Charles R. Foster, Educating Congregations. The Future of Christian Education, Nashville (Abingdon) 1994.

8 E. Byron Anderson, Worship and Christian Identity. Practicing Ourselves, Virgil Michel Series, ed. Don E. Saliers, Collegeville, Minn. (Liturgical Press) 2003.

9 Thomas Groome, Christian Religious Education. Sharing our Story and Vision, San Francisco (Harper \& Row) 1980; Thomas H. Groome, Sharing Faith. A Comprehensive Approach to Religious Education and Pastoral Ministry, San Francisco (HarperSanFrancisco) 1991.

10 Maria Harris, Teaching and Religious Imagination. An Essay in the Theology of Teaching, San Francisco (Harper Collins) 1987.

11 Anne E. Streaty Wimberly, Soul Stories. African American Christian Education, Nashville (Abingdon) ${ }^{2} 2005$.

12 This exercise was designed to embody the concept of "incorporating practice" as described by: E. Byron Anderson, Liturgical Catechesis. Congregational Practice as Formation, in: Religious Education 92, 1997, 349-362. 
of such engagement is a broadened imagination about the possibilities of the practice and a repertoire of approaches to draw on, improvise with, and forge into new forms of practice.

\section{Practices to Help Students Learn to "Read" an Educational Setting}

Several teaching practices contribute to students' abilities to recognize formative dynamics in a particular educational setting. One of the first steps in engaging a new practice such as education involves the capacity to understand what contributes to the work of education in any particular setting. Students are learning the "language" of education: the relationship between teacher and student, the formational work of the learning environment, the dynamics of group relations, and the various approaches to teaching and learning engaged. Professors will often name this as a specific learning goal on syllabi in religious education, and classroom activities and student assignments often are designed to enhance this learning goal. Some examples include:

- Visiting an educational setting and writing a thick description or a critical analysis of what is happening in a particular educational event;

- Pairig a visit to an educational setting with some heuristic categories that the student has learned; ${ }^{13}$

- Interviewing an educational practitioner in a setting to obtain a better sense of how to read the particular contextual nuances of the setting;

- Discussing in class the process of the current class or reflection on the broader school context;

- Exploring examples from students' experiences of religious education in local communities of faith in classroom discussion, drawing upon the experience already present; ${ }^{14}$ and

- Critically reflecting on case studies and critical incidents with a particular eye for the dynamics of power in student/teacher identities, the characteristic methods utilized in teaching, and how the environment is teaching. ${ }^{15}$

13 For example, Eisner's notion of explicit, implicit, and null curriculum is a fairly common set of heuristic categories used to analyze the various layers of teaching occurring in any educational environment. Elliot W. Eisner, The Educational Imagination, New York (Macmillan) ${ }^{2} 1985,87-107$.

14 Most adult learning theory emphasizes the importance of drawing on extant experience in teaching adults. A summary of some of this research can be found in: Dorothy Mackeracher, Making Sense of Adult Learning, Toronto (University of Toronto Press) 22004, 32-38.

15 For a description of critical incident exercises and their use in educating practitioners, see: Stephen D. Brookfield, Developing Critical Thinkers. Challenging Adults to Explore Alternative Ways of Thinking and Acting, San Francisco (Jossey-Bass) 1987, 97-100. 


\section{Practices to Help Students Learn to "Read" Broader Cultural Contexts}

In addition to the practice of reading a particular educational setting, many pedagogical practices in the discipline of religious education work to improve students' capacities to recognize the broader social structures and cultural dynamics affecting the contexts into which educational interventions occur. ${ }^{16}$ For example, Dori Baker's syllabus, entitled "Adolescent Worlds," names as a course objective, "To demonstrate understanding of the complex, multiple worlds youth negotiate daily, especially as those worlds reflect racism, economic inequalities, and gender bias." ${ }^{17}$ This kind of understanding is critical for sensing the formation and malformation that has already occurred in other contexts prior to any intentional form of educational intervention. This kind of awareness helps students to better negotiate what educational psychologist Shoshona Feldman highlights as "those things the learners cannot afford to know or dare not let themselves know." 18

Religious educators design various pedagogical practices to enhance this capacity in students, including:

- Reading nonfiction and autobiographical accounts of particular contexts; ${ }^{19}$

- Viewing films and documentaries such as the "Dreamworlds" series, which documents the link of sexuality and violence against women in music videos; ${ }^{20}$

- Reading social theory and political theory; ${ }^{21}$ and

- Assigning students to interview educational participants, engage in oral history projects, or complete modified forms of ethnographic research.

16 Note the similarity of this characteristic pedagogical element and the subsequent one to the first movement of Don Browning's method for engaging in practical theological reflection (descriptive theology), which is animated by the question "How do we understand this concrete situation in which we must act?" Don S. Browning, A Fundamental Practical Theology. Descriptive and Strategic Proposals, Minneapolis (Fortress) 1991, 55.

17 http://fld.ustc.edu.cn/123/xujiajin/papers/Adolescent\%20Worlds.pdf (January 2008).

18 Feldman's concept is explored in: Michael Warren, At this Time, in this Place. The Spirit Embodied in the Local Assembly, Harrisburg (Trinity Press International) 1999, 1.

19 For example, youth ministry classes often use nonfiction accounts of adolescent life. Niobe Way, Everyday Courage. The Lives and Stories of Urban Teenagers, New York (New York University) 1998; Evelyn Parker, ed., The Sacred Selves of Adolescent Girls. Hard Stories of Race, Class, and Gender, Columbus (Pilgrim Press) 2006.

20 Dreamworlds II. Desire, Sex, and Power in Music Video, prod. Sut Jhally, 55 min., Media Education Foundation, 1995, videocassette. http://www.mediaed.org/videos/MediaGenderAndDiversity/Dreamworlds2 (January 2008).

21 Thandeka, Learning to Be White. Money, Race, and God in America, New York (Continuum) 1999. 


\section{Engendering Characteristic Modes of \\ Theological and Pedagogical Analysis}

Professors of religious education generate theological and pedagogical analysis through characteristic questions that students are taught to ask of curricula, models, or approaches to religious education. The characteristic questions that students are trained to ask may structure the writing assignments, or are included as part of the evaluations of the work of their student peers. By repeating the questions in multiple areas of the class, professors slowly teach students to take on the questions for themselves and begin to think as practical theologians reflecting on educational practice (such as using the same set of questions for discussing a particular text in class and for evaluating an educational event in a local church). The following kinds of questions become an involuntary form of analysis upon engaging any educational event or materials. ${ }^{22}$ In terms of pedagogy: What gives the teacher the authority to teach? How is that authority wielded? What content is being taught? Is it appropriate to the audience developmentally, culturally, etc.? Who is included and who is left out in assumptions about the identity of the intended audience? What are the assumptions about how people learn and why they would want to learn that are operating in a given situation? How is the environment teaching? What would be an indication that students have learned something here? In terms of theology: What is faith and how does it increase? How is the Holy Spirit understood to be at work in this community? What images of God fund the identity of this community? How is salvation understood in this community and how does it relate to educational ministry? What theological anthropology is at work in this model (for example, what understandings of sin and grace are operant)? As students are asked to analyze mass-produced curricula or to reflect on the work of fellow students as they teach, the questions inform a richer, more in-depth understanding of what is happening.

\section{Engaging Creatively, Constructively, and Reflectively in the Practice of Religious Education}

One of the distinctive elements of teaching religious education is that students do not generally reflect on the practice of education solely in abstraction. In fact, most students are engaged constructively and reflectively in the practice of religious education during the course of the class

22 Boys developed a helpful set of foundational questions in the field of religious education that informs this set of questions. Mary C. Boys, Religious Education. A Map of the Field, in: Education for Citizenship and Discipleship, ed. Mary C. Boys, New York (Pilgrim Press) 1989, 102-105. 
itself. ${ }^{23}$ In addition, at the seminary or theological school level, few students come to the classroom without some hands-on experience in the practice of religious education in a local community of faith, either prior to their graduate studies or in a field education setting. The following practices, when engaged in the classroom, allow students both to engage in religious education and to reflect critically upon that engagement:

- Students design educational events or write curriculum;

- Students teach a practice event with classroom colleagues or lead an event with "real" students in a local church or other setting;

- Students engage in group presentation/teaching moments in the classroom, such as leading an opening devotion or making a classroom presentation; or

- Students engage in self-critical and collegial reflection on this practice, often using the repetitive questions mentioned in the preceding section.

In medical education, students learn procedures through a "see one, do one, teach one" method. Similar to this rhythm, students of religious education often experience a model or approach in the classroom, lead the approach, and eventually train volunteer teachers in their own setting in the approaches they know best.

\section{Reflection on the Self Who Practices}

One part of teaching religious education is helping students reflect on themselves as practitioners: their sense of purpose, social location, responsibility, and power and authority as a teacher/educational leader in a religious community. I think this is a signature element of pedagogy across the disciplines of practical theology. An example of this is found in the syllabus for "The Practices of Teaching," by Mary Boys and Kathleen Talvaccia. One activity in their class is analysis of students' past experiences of being taught and teaching, and then probing the implications of this experience for their own teaching. They note: "Thus, participation in this course requires the pursuit of deeper self-knowledge and the willingness to inquire into the implications of one's biography, and thereby engage in developing a spirituality for teaching." ${ }^{24}$ Pedagogies of religious education respect that student identity and experience affects the capacity to educate, and that the practice of any religious educator emerges from this identity. ${ }^{25}$ Thus, reflection on the self becomes a critical element in the development of a practitioner of religious education.

23 For a discussion of the importance of this form of pedagogy in educating practitioners, see: Donald A. Schön, Educating the Reflective Practitioner, San Francisco (Jossey-Bass) 1987, 22-40 (chapter 2: "Teaching Artistry Through Reflection-in-Action").

24 www.aarweb.org/syllabus/syllabi/b/boys/the_practices_of_teaching-boys.html (January 2008).

25 Palmer develops a similar thesis: “...[G] ood teaching cannot be reduced to technique; good teaching comes from the identity and integrity of the teacher." Parker J. Palmer, 
How does this happen? Professors invite students to develop and articulate a personal "theology of teaching" as an assignment. Students are invited to write a journal entry or reflective essay on their sense of vocation as an educator. Teachers ask students to locate themselves in relation to cultural and social formation (develop/demonstrate self-awareness about social location, racial/ethnic background, gender, class, or sexual orientation) in an assignment or as they analyze particular forms of educational practice. Students engage in collegial reflection on and assessment of each other's teaching and leadership of educational events. Each of these assignments and activities requires disciplined reflection on the self at the center of the practice of religious education.

\section{Challenges in the Pedagogy of Religious Education}

One of the biggest challenges in teaching religious education is deconstructing foreclosed or limited understandings of the practice arising from students' prior experience. For example, students may understand religious education as simply teaching Sunday School to children. Students are often more eager to hear the tips, tricks, and techniques for choosing curriculum and recruiting volunteers than to be taught how to read a context or an educational event, or to engage in a careful theoretical exploration of the philosophical or theological underpinnings of a particular approach. Students often bring a wealth of prior experience in education to a graduate classroom, such as many years of teaching in public schools, or years of teaching Vacation Bible School or adult education classes in a community of faith. This prior experience can sometimes be an incredible resource but at other times a genuine liability, particularly when this experience has been deadening rather than life-giving.

A second challenge is conflict between the standard forms of pedagogy and norms of educational assessment in graduate theological education and what goes on in a religious education classroom. Students may experience the modeling of more experiential and affective forms of learning in the classroom as in conflict with traditional forms of assessment, particularly grading, or where certain forms of learning have historically received greater value. Professors then struggle to balance the institutional demands for objective assessment of student learning with the pedagogical demands of educating capable practitioners.

The Courage to Teach. Exploring the Inner Landscape of a Teacher's Life, San Francisco (Jossey-Bass) 1998, 10. 
Teaching Toward Faithful Practice: Pedagogy for Liturgical Studies in Christian Seminaries and Divinity Schools

\section{John D. Witvliet}

How should Christian worship be taught to prospective ministers and other seminary-trained liturgical leaders? Since 1965, when there were no full-time professors of worship in North America, to today, when there are more than three hundred members of the North American Academy of Liturgy, the need for teaching liturgy in the seminaries and divinity schools has become well established. There is little consensus about how the subject should be taught, however, particularly for the introductory courses that are likely to be the only courses in liturgy or worship that most students take. ${ }^{26}$ Some basic courses offer an introduction to the discipline of liturgical studies, others skim the history of worship, probe recent work in ritual theory, focus primarily on sacramental theology, or attend mostly to strategies for getting along with church musicians. In light of this varied pedagogical terrain, my aim here is to map a "practices approach" to teaching worship. This approach presses beyond both mere technique and mere objective analyses of worship to form students in the knowledge, wisdom, and capacities for vital and faithful liturgical leadership. In this paper, I will briefly suggest the goals, starting points, methods, and ethos for such an approach. ${ }^{27}$

\section{Overarching Goals}

Many worship courses function as an introduction to liturgical studies, much like a college introduction to sociology course. Yet while introducing students to the vocabulary, methods, and key concepts in worship is commendable, it is crucial to aspire to something deeper. Students need to be formed not just to understand worship but to practice it, and to shape the practice of others. Focusing courses in the practice of ministry transforms them from introductions to a discipline into a training camp for "full, conscious, active" liturgical participation. This change of orientation affects every class. ${ }^{28}$ For example, discussions of the eucharist that merely

26 I am grateful two earlier reflections on pedagogy for liturgy: James F. White, The Teaching of Worship in Seminaries in Canada and the United States, in: Worship 55/4, 1981, 304-318; and Edward Foley, Training Church Musicians. What Are the Appropriate Methods? in: Theological Education 34/2, 1998, 17-24.

27 A longer version of this essay appears as: John D. Witvliet, Teaching Worship as a Christian Practice, in: Dorothy C. Bass/Craig Dykstra, eds., For Life Abundant. Practical Theology, Theological Education, and Christian Ministry, Grand Rapids (Eerdmans) $2008,117-148$.

28 For more on mutual accountability for the purposes of learning as spiritual formation, see: Karen Marie Yust/E. Byron Anderson, Taught by God. Teaching and Spiritual Formation, St. Louis (Chalice Press) 2006; Michael Battle, Teaching and Learning as Ceaseless Prayer, in: The Scope of Our Art. The Vocation of the Theological Teacher, ed. L. Gregory Jones/Stephanie Paulsell, Grand Rapids (Eerdmans) 2002. 
analyze competing eucharistic theologies or offer commentary on ancient rites are hardly sufficient. Practice-oriented discussions must include this theological and historical analysis, but also must probe how patterns of liturgical leadership, education, pastoral care, and social ministry can help congregations participate in the Lord's Supper more deeply. Almost inevitably, this participation-oriented approach leaves time for fewer topics, but it also creates a context in which good historical and theological work can actually have traction for deepening present-day practice.

Second, a practices approach calls for highlighting the communal dimensions of liturgy. Future presiders must learn to encourage the participation of children and the elderly, those challenged by career success or mental illness, persons who cling to the church as their only source of community and those who resist the church because of the pain it has caused them. Simple assertions that "worship resists our individualistic culture" mean little without probing how to encourage faithful liturgical participation with very different kinds of ordinary people.

A communal orientation calls for training leaders who will be "catalysts for collaborative worship ministry" rather than "solo pilot leaders." In most congregations, worship is led by multiple leaders. Even the simplest services often involve a presiding pastor and a musician. Yet some books and courses assume that their audience is a solo pilot leader. In contrast, books and courses with titles such as Designing Worship Together encourage the use of complementary gifts of multiple participants. ${ }^{29}$ Future pastors need not become experts in liturgical music or architecture, but they do need a way to conceptualize, teach, plan, and evaluate worship that will help them support and learn from others with those gifts.

Third, worship courses should be taught with a sense of how worship fits into a well-balanced communal Christian life. It is tempting for those of us who teach courses in pastoral care, education, preaching, missions, and worship to suggest that faithful pastors need to spend at least thirtyfive hours a week on tasks related to each specialty. The only healthy way to move beyond this impossible ministerial mathematics is for pastors and those who teach them to perceive how each area of ministry is intertwined with the rest. Liturgical ministry at its best intersects with, draws on, and shapes every other ministry task. Thus, the scope of inquiry for courses in worship is nothing less than a Christian way of life viewed through the prism of communal worship. Nearly every subject on the syllabus suggests connecting points between liturgy and life. Imagine, for example, a discussion on how to prepare worship for the anniversary of a major earthquake or tsunami. The topic connects quickly with approaches to church education, pastoral care, social justice, mission and witness, as well as evoking themes in systematic theology and biblical studies. In this context, there

29 Howard Vanderwell/Norma de Waal Malefyt, Designing Worship Together. Models and Strategies for Worship Planning, Herndon, Va. (Alban Institute) 2004. 
is little reason why liturgical studies courses cannot be among the most interdisciplinary courses in the divinity school curriculum.

\section{Starting Points}

To be sure, achieving these goals is made more complex by the fact that worship courses never begin with a blank slate. For starters, we teach in the middle of a long and complex stream of practices, including not only different rites, sacraments, or ordinances, but also different patterns of leadership, musical and architectural traditions, and quite different cultural sensibilities about exactly when a given service has gotten to be a bit long. The best courses help students appreciate some of the complex social, intellectual, and cultural dynamics involved in practices they may well have taken for granted. Learning the piety that led to adopting the sanctus from Isaiah 6 as a regular element in eucharistic prayers, the pneumatology behind the prayer for illumination, the social history that led to worship spaces that look like theaters, or the life stories of a contemporary song writer can each lead to new awareness of the strengths and weaknesses of exciting practices, and prepare students to both receive and shape the traditions they have inherited.

We also teach students who have already been formed in complex patterns of liturgical participation. Students sometimes arrive in our classes with opinions about worship, and sometimes with suspicions about their professors' closed-minded attitudes. Conversely, some of us who teach return the favor, unwittingly thinking of students' prior liturgical experience as irredeemably deficient. The worship classroom needs to expose and interrogate each of these barriers to learning. One gentle strategy I have found useful on the first day of class is simply to ask students (and myself) two questions: "What is your favorite style of worship?" and "What liturgical experiences have transformed your outlook on the beauty of God and the shape of a faithful Christian life?" This begins to detach stylistic preferences from deeper questions of formation, to suggest a vocabulary and criteria by which we will judge liturgical practices, and to offer students a pastorally constructive way to approach future ministry settings.

\section{Pedagogical Approaches}

\subsection{The Tangible and the Quotidian}

A practices-approach to teaching worship also shapes the basic contours of the syllabus, giving primary attention to concrete, observable actions in extraordinary and ordinary places. Courses in worship are like courses in theater and music. They attend to "performances" that unfold through time. A significant amount of energy should be reserved for encountering actual practices: concrete examples of gestures, symbols, sermons, songs, images, and environments. 
One temptation here is that of giving priority to only the grandest, idealized types of liturgy. This can be inspiring, but is not necessarily helpful for prospective ministers who may well spend several years in congregations with only minimal resources in music, art, or theological imagination. The move toward concreteness must also be a move into the ordinary. This is not to say that students should never be exposed to the drama of a papal funeral or a megachurch Christmas celebration. In fact, seeing human foibles in these settings can powerfully reinforce the tangible, quotidian, messy nature of ministry. What is needed is the juxtaposition of the grand and the ordinary, the grand-among-the-poor and the ordinary-among-the-rich that helps students see what is at stake in any liturgical performance.

Looking at tangible practices also does not mean that the classroom needs to be pedestrian or prosaic. Each tangible, ordinary practice presents an opportunity for attention to multiple layers of meaning. Practice-oriented teachers who are eager to discuss a question like "What capacities does a congregation need to experience the full range of biblical eucharistic metaphors?" might naturally draw on a range of resources and disciplines:

- Ethnographic studies and constructive theological proposals of how children experience the Lord's Supper;

- Historical and contemporary commentaries on biblical texts of the Lord's Supper;

- Analyses of how confessional statements and ecumenical dialogues clarify common understanding within and across traditions, or how analytic philosophers clarify the metaphors and concepts used in eucharistic theology;

- Explorations of how issues in congregational life modify eucharistic practice (such as generational identity in immigrant congregations or leadership patterns in congregations with fewer than fifty members);

- Rhetorical reflections on language strategies writers use when communicating with a general audience, as well as how cinematic portrayals of the eucharist reveal or conceal key themes;

- Analyses of how visual and architectural gestures evoke or contradict biblical eucharistic metaphors, or how the ritual patterns and musical gestures of particular congregations reveal patterns of participation; and

- Discussions of differences between public worship and private devotional practices, how the prayer texts that accompany the eucharist evolved over two thousand years, and what kind of process is best suited to their reform and adaptation.

The libraries of practice-oriented liturgical theologians need to be fusion experiments that draw on research in a large range of disciplines: social, intellectual, and material history, sociology of religion, rhetoric, ritual theory, developmental and cognitive psychology, religious journalism and photojournalism, ethnography, aesthetics theory, art history, architecture, 
communication theory, and economics. To be sure, the richness of this material creates the possibility that worship syllabi can be too sprawling and superficial. The challenge for every topic is to find guiding questions that match the topic's complexity, focus discussion, and create curiosity that motivates further learning.

\subsection{Integrating Liturgical Mechanics and Liturgical Theology}

Part of this complexity can be managed by regularly intertwining discussions about the theology and mechanics of liturgy. At their best, worship courses hone a stereoscopic vision that attends both to concrete liturgical procedures and to implicit theological meaning. For this to work, courses need to offer sustained reflection on overarching theological themes (such as the priesthood of Christ) and discussions of quotidian practices (such as how to distribute the elements of communion). For example, in Leanne Van Dyk's A More Profound Alleluia, each chapter both illustrates how particular moments (like eucharist) reflect and shape attitudes toward doctrinal themes (like eschatology), and provides two hymn texts (themselves liturgical artifacts) that speak evocatively about a given theological theme. ${ }^{30}$ This volume sets the stage for class sessions that integrate attention to liturgical prayers and hymnody, key biblical texts, and theological claims, as well as to the skills and details involved in leading worship.

Oddly, the connection most in need of further development in many contexts is the obvious connection of worship to God. In fact, too many books and courses about worship say little directly about God. To be sure, the practice of worship is a tangible activity that involves material objects and physical actions, but these are invariably influenced by how communities conceive of the deity they address. Effective practice-oriented worship education uncovers and explores this connection. My colleague from Asbury Seminary, Lester Ruth, gives his students overarching questions for his introductory courses like these:

- If Jesus Christ is truly and fully the incarnate God, what impact should that have on Christian worship?

- If the gospel is a comprehensive story remembering God's activity from beginning to end, what impact should that have on Christian worship?

- If Christian worship forms us to be certain kinds of Christians, then what should our priorities in worship be?

- If God is triune, does that make any difference in how we worship?

These questions set the stage for semester-long engagement with some of the most significant Christian theological claims. Without naming these kinds of questions, we risk teaching that perpetuates the impression that doctrine and practice are unrelated. More profoundly, we risk promoting

30 Leanne Van Dyk, ed., A More Profound Alleluia. Worship and Theology in Harmony, Grand Rapids (Eerdmans) 2004. 
an approach to worship that offers little awareness or expectation of divine presence or action. The study of worship, and indeed all of practical theology, suffers when it ceases to be theological. It is at this essential point that practices-oriented teaching strongly resists reduction to mere technique.

\subsection{Practicing Basic Skills for Improvisatory Ministry}

It would be equally problematic, however, to ignore technique. Without practical training in specific leadership techniques and approaches, ministers are likely not to practice the wisdom explored in a given worship course, no matter how compelling and fruitful it might be. Teaching technique is not easy, however. Musicians have agreed-upon scales to learn. Soccer players know the importance of dribbling and passing exercises. There is little consensus about what scale-like drills future minister should master. Consider a sampling of possibilities:

- Identify three appropriate songs or hymns for a funeral of someone you know.

- Prepare one-sentence introductions to the scripture readings.

- Practice a gesture to accompany leading a prayer that communicates warmth and hospitality.

- Write an extemporaneous welcome for a liturgy in a particular congregation.

- Memorize a one-verse call to worship from the Psalms and practice saying it in an inviting, engaging way.

It is also possible to press on to exercises with deeper significance:

- Read an excellent newspaper and reflect what you read there as you prepare an intercessory prayer.

- Study an assigned scripture text and choose visual art that evokes the text in a provocative and faithful way.

- Reflect on a pastoral care encounter and choose liturgical music for a eucharistic celebration that weaves the needs of that particular individual and the communal, eschatological nature of the Lord's Supper.

Through such exercises, students prepare to engage in the inherently improvisatory nature of ministry. Every golf or tennis shot practices the art of improvisation, taking the timeless virtues of a good swing and calibrating them to the wind conditions. So, too, the Christian life and the practice of ministry involve taking habitual questions and actions and calibrating them to particular conditions of a given time and place. ${ }^{31}$

This also requires that some attention be given to times of congregational dysfunction. Books about worship and worship courses often assume fair weather conditions. Yet worship leadership often happens,

31 Daniel T. Benedict, Jr., No Cowardly Spirit. Teaching Pastors and Priests to Preside, in: Liturgy 22/2, 2007, 27-34. 
and is most pastorally significant, in times of uncertainty, crisis, conflict, or transition..$^{32}$ In these contexts, leaders may rely on the same techniques for imagining a sermon, preparing a prayer, or choosing music as in other times, but they need to negotiate the unique dynamics that attend to congregational life during those times.

\section{Ethos}

Finally, how does a practices-approach affect the feel of a worship course? Every class on every subject inevitably introduces students not only to concepts and questions, but also to a "culture," as typical courses in military leadership, water polo, master gardening, and drag car racing would readily exemplify. The obvious question in teaching liturgy is simply: How can worship courses be taught in a way that evokes worship and cultivates the kind of awe and gratitude that is the root of genuine worship? For one, courses can themselves include times of liturgical prayer, scripture reading, and blessing. For another, course readings and other assignments can be chosen not only because they are instructive, but because they are evocative and worshipful, readings like Psalm 63, Revelation 5, Egeria's diary of a fourth century liturgical pilgrimage, Bonhoeffer's Life Together, John Wesley's Instructions on Singing, or a Pablo Sosa hymn. This concern can also shape the mode of engaging these texts. Students can be asked to meditate on one of Augustine's sermons on the eucharist rather than to skim a thirty page essay analyzing his view of the sacraments. Instead of analyzing a baptismal prayer, students could memorize one. Rather than scrutinizing hymns, students can sing them. To the extent that it forms a capacity for wonder (or even suggests its significance), a genuinely doxological ethos may be as important for a worship course as any particular assignment.

Over the span of two thousand years, periods of significant liturgical reform have featured calls to more intentional participation in worship, pastoral concern for the complexity and particularity of worship in a given congregation, and a profound awareness of how God works to nourish, confront, and inspire participants through worship. This triad of themes also grounds effective practice-oriented teaching. A pedagogy focused on deep participation is resolutely set against disengagement, neutrality, and cynicism. A pedagogy of depth and complexity is resolutely set against shallow, sentimental, or simplistic liturgical explanations or prescriptions. A pedagogy of responsiveness to God corresponds to the dynamics of divine grace, embracing tangible liturgical actions by real people in ordinary communities as means of grace. Taken together, these convictions guide an approach which forms prospective ministers for vital and faithful leadership in a hurting and broken world.

32 Kathy Smith, Stilling the Storm. Worship and Congregational Leadership in Difficult Times, Herndon, Va. (Alban Institute) 2006. 


\section{Pedagogy in Practical Theology: \\ Two Problems in the Case of Pastoral Care}

\section{Kathleen J. Greider}

The writer Anne Lamott says that "grace means you're in a different universe from where you had been stuck, when you had absolutely no way to get there on your own." ${ }^{33}$ Like so many professors, I was taught a subject, but not taught to teach the subject, so my experience in teaching is often like that: I am uncertain about how to proceed, and grace intervenes. I have learned much about this vocation after sixteen years of teaching, yet still I experience fairly consistent puzzlement and sometimes even distress about how to teach my discipline in ways that adequately serve my students and the persons with whom they minister. For these reasons, I find myself a surprising candidate to address this topic. It is also the case that I think my situation is not merely idiosyncratic but reveals something about challenges in my discipline. Therefore, I offer brief reflections on two areas that raise significant challenges in the teaching of pastoral care: the scope of the discipline and its focus on soul-care. ${ }^{34}$

\section{Scope of the Discipline}

I have not yet discovered how to teach my discipline with integrity and effectiveness given its growing scope. What James Woodward and Stephen Pattison say of practical theology is true as well of pastoral theology and care: "In principle, the scope of practical theology is almost infinite." 35 It is no longer clear either in theory or practice where the boundaries of the discipline of pastoral care lie and, however justifiable, the expansiveness is a serious problem for teaching and learning. Since it was first articulated in the middle of the twentieth century, a widely embraced principle in pastoral care in the U.S. is that our primary "text" is "the living human document." 36 At first that statement served to express both a focus for the discipline and also that the discipline made a distinctive and scholarly contribution within the theological academy. For some disciplines, the Bible is the primary text. For others, texts of Christian history and

33 Anne Lamott, Plan B. Further Thoughts on Faith, New York (Riverhead Books) 2005, 54-55.

34 My experience and reflections are further contextualized by the fact that I teach pastoral care in the U.S., in one of the most ethnically and religiously diverse regions of the world, and in a school that is a hybrid (a seminary of an oldline Protestant denomination and a school of theology related to a university).

35 James Woodward/Stephen Pattison, An Introduction to Pastoral and Practical Theology, in: The Blackwell Reader in Pastoral and Practical Theology, ed. James Woodward/Stephen Pattison, Malden, Mass. (Blackwell Publishing) 2000, 8.

36 Anton Boisen is credited with being the first to describe in this way the focus of study and practice in pastoral care. See: Glenn H Asquith, Jr., ed., Vision from a Little Known Country. A Boisen Reader, Decatur, Ga. (Journal of Pastoral Care Publications) 1992. 
theology are the center of study. For pastoral care, however, living, breathing humans are the central "text" for our study, teaching, and learning. Even so, developments in the last few decades have both nuanced and expanded to a radical degree our comprehension of the nascent meaning in that statement of disciplinary self-understanding. I will sketch changes in pastoral care specialists' understanding of the phrase as a means to describe the expansion of the discipline's scope. ${ }^{37}$

When pastoral caregivers first started thinking of the living human document as our primary text, the text most of us studied was the person. That seemed relatively manageable, at least to those of us who assumed harmony and commonalities among people and universalized our learnings. Largely due to the influence of feminism, however, pastoral care specialists realized that we had been wrong. Because human beings are inextricably interconnected, the document that is our primary text is relationality, and we began to say that our primary text is the living human web. ${ }^{38}$ The document was becoming more unwieldy, but feminist and family systems theories anchored some of us. Then, developments like globalization and postmodernism, with their explications of context, otherness, and particularity, revealed that many of us had been insufficiently aware that our inextricable interconnections are both international and cross-cultural in scope. Now most of us agree that our capacity to read and comprehend the document that is the human web depends on the extent of our multicultural and intercultural competencies. The very notion of the web has also been problematized by racism, genocide, war, colonialism, slavery, poverty. Is there one web? Maybe we are wrong. How can we claim one web when it provides security for some by causing death to others? If there is one web, it hangs in shreds because of injustice.

In any case, it is clear to pastoral care specialists that the whole human document is threatened when there is injustice anywhere. Our caring must be directed not only to where relationality is broken but also to the complex social circumstances that have broken it and to the social reform required if people are to be empowered to come together again. If all these dimensions are to be understood and influenced, it is clear that we must study the text of the living human document with a multidisciplinary analysis: effective teaching, learning, and ministry attend to history, economics, politics, sociology, psychology, the arts, health care, and all scholarly tools that shed light on the living human document. Most recently, we have become aware that our theories and practices must be

37 This expansion is detailed in: Nancy J. Ramsay, ed., Pastoral Care and Counseling. Redefining the Paradigms, Nashville (Abingdon Press) 2004.

38 Bonnie J. Miller-McLemore, The Human Web. Reflections on the State of Pastoral Theology, in: The Christian Century 110/11, 7 April 1993, 367; Brita Gill-Austern, Rediscovering Hidden Treasures for Pastoral Care, in: Pastoral Psychology 43/4, March 1995, 233-253. 
sensitive to spiritual and religious differences within the web, so much so that some specialists are now calling the discipline spiritual care, not pastoral care. If we were to discuss what it means to "care," the parameters of our theory and practice would be extended even further.

All these expansions in the way we understand the "primary text" of the discipline of pastoral/spiritual care are necessary. At the same time, these expansions raise serious problems for teaching and learning. This enormous range of concerns complexifies theory and practice, and raises difficult questions about obligation, expertise, ethics and sustainability. Given this broad scope of concern, what is the particular responsibility and special expertise of the effective pastoral caregiver? Given the necessity for so many areas of knowledge, what is the ideal or adequate education for pastoral caregivers? Given the limitations of human capacities to develop multiple areas of expertise, is there anything to which the pastoral caregiver ought to say (as pastoral counselors and other mental health caregivers are legally obligated), "Unfortunately, that is outside my scope of practice; ethics require that I refer you to someone with expertise in that area." How do we balance such rightful concern for ethical practice with the call to be responsive when G-d is doing a new thing? For example, I recall the time when a Buddhist student, who was enrolled in my introductory course because he wanted to be a chaplain but could find no course of study in Japan, asked me, "Professor, Buddhism teaches no-self, so I wonder if you will please help me understand the role of selfreflection in soul care within the Buddhist context?" That I am called to respond to increasing religious diversity in my seminary classroom and in the human family, yet have so little education in religious traditions other than Christianity, is but one example of the problematic nature but also essential call of the ever-expanding discipline of "pastoral" care.

The breadth of our scope is pressed upon us by the changing needs of the human family, even if our capacities to respond are limited in significant ways. With the call to care of souls so expansive and the boundaries of caregiving hard to identify, however, what are we teaching students about ministry? Should they set any limits on their availability and response? If so, how are those limits to be identified, especially given that ministers in so many communities are the first professional to be called and last line of defense against neglect? At this point, it seems that this is our operating principle, or at least our null principle: If called upon, we must try to respond competently to any human situation that presents itself to us. Again, this seems necessary. Even so, no amount of faithfulness or training changes the fact of our human limitations. We need to be more articulate about our limits, and how, besides the very important practice of referral, we take those limited competencies into account in theory and in practice. We need to be more articulate about what constitutes the scope of the discipline and how we triage the many acute dimensions of the human document that call for our attention. 


\section{Focus on Soul-Care}

Within such an expansive scope of concern, my students and I need a touchstone on which we can center ourselves when shifting theories and practices make choices and priorities necessary. For some time now, this question has provided that touchstone: What constitutes soul-care in this situation and how can we cultivate or conjure the capacity to embody it in contextually appropriate ways? This seems to me to be one valid way to specify the particular responsibility and obligation of my discipline. Similarly, Emmanuel Lartey addresses in his most recent book the scope of the discipline by centering on care: "Basic to the scope of pastoral theology is a requirement to include in its study and practice all that has to do with the care of persons and communities within the global village." 39 Amid the turmoil, this becomes my pedagogical principle. Whatever else changes, persons trained in my discipline ought to be specialists in the questions, challenges, practices, and standards of care. Yes, we need to revise many of our theories and practices. We need to increase our attention to systems, and to care for congregations as well as congregants, to nurture soul-wisdom and not only self-esteem and, assuredly, our assumptions about care itself must be contested and contextualized. The standard and purpose, though, the home base which helps us conceptualize a playing field, is the question: In this situation, what soul-care is needed and what will it take to provide it?

In some ways, the centrality of care serves as a pedagogical advantage for my discipline. Many students come to pastoral care courses eager to learn. More than a few say, with the guilelessness of beginners, "I'm not very good at theology, but I think I'll be able to do a really good job in this course, because people have told me that I'm a good listener and I really like to help people." The advantage of the popularity of pastoral care classes soon turns to ash, however, because of what I think is a pedagogical principle in pastoral care: We think we want to learn pastoral care, but we really don't. Care is so often painful and exhausting and demoralizing. As Peggy Way has put it so succinctly, "pastoral knowledge is generally not welcome knowledge." 40 The focus on soul-care poses pedagogical problems because, by definition, it cultivates pastoral knowledge that is so often unwelcome.

39 Emmanuel Y. Lartey, Pastoral Theology in an Intercultural World, Cleveland (The Pilgrim Press) 2005, 30. A few pages earlier, Lartey states his view of the scope of pastoral theology somewhat more specifically. The discipline "operates around and studies the central themes of faith-inspired care and care-inspired faith." Pastoral theologians and caregivers "focus on studying 'care' and 'faith' and the interrelationships between them." (28) Because the language of faith is not meaningful across all religious traditions, I find the statement above more useful in a religiously diverse classroom.

40 Peggy Way, Created By God. Pastoral Care for All God's People, St. Louis (Chalice Press) $2005,165$. 
Pastoral knowing is unwelcome because it reveals the horrific and unrelenting existence of suffering, sin, and evil, and a remarkable number of students find it difficult to believe what they learn. This tendency was dramatically demonstrated by the student in my course on trauma and recovery who, after a few weeks of study, declared to me that there could not possibly be this much violence between human beings, and that my perspective must have been warped by too much reading about it. Even those who are not in this state of denial find pastoral knowledge unwelcome when they realize that there is little they can do to alleviate suffering and that they often must instead move closer to it, sit down, be slow to speak, be quick to listen. At least at first, most students do not really want to learn the spiritual maturity and endurance it takes to resist the instinct to flee suffering and instead to offer to suffering ones the ministry of our presence. It takes a long time for students to welcome the knowledge that the mystery of suffering is frequently impenetrable and that the humbling and vulnerable practices of silence, wondering, and waiting are the requirements of presence.

Pastoral knowing is also unwelcome, at least initially, for the many students who come to class prepared to study other people's problems, but not their own. They find out that other people's lives are not the only primary text. In a pastoral care class, they must study analytically the text of their own lives. There are students who expect the pastoral care class to be a slam-dunk and are surprised to find out that intellectual intelligence does not guarantee emotional intelligence. ${ }^{41}$ There are disciplines to practice and standards to meet on the way to what, in the context of ministry, is more accurately called psychospiritual intelligence. Because students so often find pastoral knowledge surprisingly unwelcome and demanding, faculty widely agree that a crucial part of pedagogy in pastoral care and counseling is that students gain skills in self-reflection. ${ }^{42}$

The self-reflection that enables pastoral knowledge is equally unwelcome in the academy. There is much in the academic world that makes it difficult for students to bring together the worlds of intellectual intelligence and emotional intelligence. In the first year at Claremont School of Theology, students take courses primarily in Bible, systematic theology, and history. In these subjects, they are taught not to write about them-

41 Daniel J. Goleman, Emotional Intelligence, New York (Bantam) 1995.

42 When bringing together nineteen professors of pastoral care to discuss teaching, Carrie Doehring and Edward Fontenot's afterword concluded that "many faculty would agree that there is one unproblematic criteria for assessing students' formation. Can students demonstrate in class assignments their ability to use self-reflection as part of a practical theological method, such that students are responsible for monitoring their own psychological and spiritual reactions to care-seekers and not allowing their reactions to interfere negatively with the pastoral care they offer?" Carrie Doehring/Edouard Fontenot, Strategies for Teaching about Pastoral Care. Implications for Theological Education in a New Millennium, in: Journal of Pastoral Theology 11, June 2001, 17. 
selves but about the subject, to learn that how they feel about a subject is largely irrelevant to a paper's argument, and that the first person singular is rarely appropriate in an academic paper. When they get to my class, I often need to teach them that in pastoral care it is essential to put the "I" back in their writing, not just grammatically but substantially. In pastoral care they are pressed to realize that writing about ourselves is writing about the subject, and vice versa. They are challenged to admit that how they feel has everything to do with how they think about a theory or a practice. Toward this end, I devise assignments with detailed rubrics for analytical self-reflective exercises: verbatims, case studies, videotapes of their caregiving, and self-reflection in written assignments. Yet no matter how hard I try to incorporate it into my teaching and assessment, students with little psychospiritual intelligence still get A's. It is as if the weight of the language and conceptualization of the academic context prevents me from faithfully enforcing what is arguably the most fundamental and widely agreed upon standard for my discipline.

Pastoral knowledge is unwelcome because it is paradoxical. Just about the time beginning students start focusing less on fixing people and their situations and more on listening, I often ask them to read the essay "When Listening Is Not Enough," written by pastoral theologian Joretta Marshall in the aftermath of $9-11 . .^{43}$ In our highly psychologized age, where privatized listening can seduce us into social passivity, Marshall asks us to consider what pastoral care looks like in the context of public crises and what pastoral theology says to contexts of political pain. As Marshall puts it,

sometimes...pastoral theology provides comfort and care; other times it is painful and disquieting as it moves beyond the confines of our individual lives to contemplate the broader and more complex realities of our communal living...We dare not settle for the easing of people's pains without challenging inappropriate or inadequate theological claims. ${ }^{44}$

There may be no more difficult challenge in pastoral care pedagogy. To teach students to assess what constitutes inappropriate or inadequate theological claims, to assess their own claims as well as others, and to assess and challenge always with respect and compassion rather than self-righteousness and impatience - this is advanced pedagogy and learning. It is nothing less than knitting back together the prophetic, priestly, and pastoral roles theological education tends to divide. From a pastoral care perspective, one of the most challenging parts of making a minister out of these roles is helping seminarians tackle the challenge of being,

43 Joretta L. Marshall, When Listening Is Not Enough. Pastoral Theology and Care in Turbulent Times, in: Strike Terror No More. Pastoral Theology and Care in Turbulent Times, ed. Jon L. Berquist, St. Louis (Chalice Press) 2002, 164-171.

44 Ibid., 167. 
for example, a pastoral prophet and a prophetic caregiver, and see that these are not contradictions in terms.

Pastoral knowledge is unwelcome because it takes so much out of us. Because the discipline is expansive and the boundaries unclear, and because there is no end to human suffering, there is a visceral, tiring sense that the work of pastoral care study and practice is quite endlessly demanding. Moreover, we have not even addressed a new set of expectations on the horizon: that our study and practice ought to attend much more to play and wellness and prevention of suffering. ${ }^{45}$ I think this is true, though I have not yet found a way to add wellbeing to syllabi already loaded down with the suffering. Amid the longstanding and emerging expectations of my discipline, I wrestle with how to tell the truth of the suffering and engage the demands of caregiving without demoralizing and exhausting my students and myself. For this reason, I try to give space in my teaching to comforting and nurturing the souls of my students. I read to them stories and poetry that massage sore human hearts. I provide opportunity each class session for two times of spiritual reflection in which they share with each other resources and practices that sustain their souls. These are only gestures, but they prod the students to remember that, given that pastoral knowledge is so often unwelcome knowledge, the sustainability of ministry rests heavily on care for self as well as for others.

\section{Summary and Conclusion}

I have noted the pedagogical problem posed by the scope of the discipline of pastoral care, and then offered that soul-care can serve as a focus for the work of caregivers within that broad scope. A focus on care poses its own pedagogical problems, though, since practices of care bring unwelcome knowledge. Both the scope and the focus of the discipline warrant more intentional discussion among pastoral care specialists, so that teaching and practice keep pace with our theoretical vision of the discipline's obligations and contributions.

45 For example, see: Michael S. Koppel, A Pastoral Theological Reflection on Play in the Ministry, in: Journal of Pastoral Theology 13/1, spring 2003, 1-12. 


\section{Creative Tension: Teaching Preaching in a Divinity School}

\section{Brad R. Braxton}

Dialectical philosophy speaks often about creative tension - an occurrence of two different, but related realities pulling away from each other, which consequently establish a tension in their midst. This tension, properly harnessed, harbors a palpable energy that stimulates growth, productivity, and most of all creativity. As a homiletician, I am acquainted with creative tension. Creative tension is the arena in which I am fulfilling my vocation. Creative tension: competing commitments that refuse to take a back seat to each other. Creative tension: recalcitrant loyalties that avoid easy co-optation. Creative tension: the indomitable hope that there are more choices on the pedagogical menu than "either/or."

When a homiletician prepares a syllabus for a preaching course, and especially an introductory course, countless questions must be addressed. I cite but a few: Is preaching taught or caught? As the professor, how much should I "teach" and how much should I "preach" in the classroom? When teaching preaching, is the ultimate goal passion or precision? When teaching preaching, is homiletics or hermeneutics more important? ${ }^{36}$ In my attempts to respond to these and other questions, I have sought to foster, not eliminate, energizing tensions. Typically, my students receive from me not "either/or" approaches, but rather "both/and" or "all of the above" approaches. Briefly, I will explore three creative tensions in my homiletic pedagogy.

\section{First Creative Tension: Is Preaching Taught or Caught?}

Should I, as the professor, teach or preach in the homiletics classroom? My response is "both/and." Perhaps, the best way to address more fully this first set of questions is to provide a portion of the first lecture in my

46 For further discussion of important issues associated with teaching introductory homiletics courses, consult classic textbooks, such as: Paul Scott Wilson, The Practice of Preaching, Nashville (Abingdon Press) 1995; and Thomas G. Long, The Witness of Preaching, Louisville (Westminster John Knox Press) 22005. Anthologies about preaching may also be helpful, such as: John S. McClure, ed., Best Advice for Preaching, Minneapolis (Fortress Press) 1998; Jana Childers, ed., Birthing the Sermon. Women Preachers on the Creative Process, St. Louis (Chalice Press) 2001; Cleophus J. LaRue, ed., Power in the Pulpit. How America's Most Effective Black Preachers Prepare Their Sermons, Louisville (Westminster John Knox Press) 2002; and Richard L. Eslinger, The Web of Preaching. New Options in Homiletic Method, Nashville (Abingdon Press) 2002. The relationship between preaching and biblical hermeneutics is discussed in: Paul Scott Wilson, God Sense. Reading the Bible for Preaching, Nashville (Abingdon Press) 2001; Brad R. Braxton, Preaching Paul, Nashville (Abingdon Press) 2004; and Dawn Ottoni Wilhelm, The Role and Authority of Scripture in Preaching, in: Believing in Preaching. What Listeners Hear in Sermons, Mary Alice Mulligan/Diane Turner-Sharazz/Dawn Ottoni Wilhelm/Ronald J. Allen, St. Louis (Chalice Press) 2005, 21-45. 
"Introduction to Homiletics" course. I have taught the course a total of ten times: eight times at Wake Forest University Divinity School and twice at Vanderbilt University Divinity School. On every occasion, I have begun the course with this lecture. I have modified the lecture manuscript very little over the years. In the earlier portions of the lecture, I define terms such as "gospel" 47 and "sermon." ${ }^{48}$ I also present several of my theological presuppositions concerning preaching. ${ }^{49}$ As I constantly remind my preaching students, a manuscript is simply a transcript for an embodied performance. The preacher, or in this case the professor, has to enliven the dead letter on the page. The following excerpt occurs in the middle of that first lecture:

What is homiletics? It is the "science" and "art" of preaching. By "science," I mean there are some rudimentary principles - one might say even axioms - that can and should be learned. These axioms hold true in most, if not all, ecclesial contexts. Homiletically, there are things that you should do whether you are in the north or the south; whether your pulpit is in a megachurch or in a storefront; whether you are preaching in Nairobi or Nashville. Science is taught. Science can often be replicated in step-like fashion. Do this in step one; do that in step two, and "ta da!" here are the consequences.

There is a substantial part of preaching that is also an "art." To be sure, art is not without rules, techniques, and principles. Yet art is a more elusive phenomenon, both in its creation and in its reception. To demonstrate what I mean, ask a songwriter, painter, or poet to give you a step-by-step process of how she created a song, painting, or poem. You might receive a blank stare from that artist. The artistic mindset is not easily captured by formulae and steps.

If you are looking for a simple "how to" book in this course, you may be out of luck. I cannot give you in this course the "how to become a preacher in twenty-eight days" formula. As a preacher, I am an artist. The poet Wen-

47 Here I mean "gospel" as the saving actions of God rather the literary productions of early Christianity (that is, the four gospels). Accordingly, I offer the following provisional definition of "gospel" in that lecture: "The gospel is the story of God's righteous intentions for the world, God's loving involvement with the world, and God's future reign over the world. A commitment to God's story calls people to the pursuit of righteousness (i.e., justice), the formation of loving relationships, and a spiritual posture that leans toward hope."

48 In that lecture, I offer the following provisional definition of a (Christian) sermon: "A (Christian) sermon is a Holy Spirit-inspired, human performance that proclaims the saving acts of God, most especially those acts of Jesus Christ. Equally conversant with ancient scripture and contemporary experience, a sermon endeavors to persuade people of its particular 'truth claims' and to create the conditions for an encounter with God."

49 In that lecture, I offer three theological presuppositions: " 1 . God is a sovereign, transcendent being with a fierce commitment to justice, a fathomless love, and an intense desire to be known. 2. Preaching is a time-honored place of God's self-revelation. Through preaching, God discloses truth about God's self and about the world. 3. When faithfully performed, preaching can and will form a Christian character in individuals and in communities. Thus, preaching possesses a profound power to transform." I do not expect my students to agree with any or all of these presuppositions. On the contrary, I state my presuppositions clearly in order to encourage them to state theirs clearly. 
dell Berry has suggested that as an artist there are two Muses who sit on my shoulders, whom I must court. One is "the Muse of Inspiration, who gives us inarticulate visions and desires." The other is "the Muse of Realization who returns again and again to say, 'It is yet more difficult than you thought.' This is the muse of form." 50

The first muse gives me the bright idea but then does not tell me how to implement it. The second muse invites me to a disciplined consideration of form. But I have discovered that at times even the second muse, the Muse of Realization, speaks in very inchoate sentences. It tells me first to pursue this and then to pursue that. In other words, the harnessing of inspiration into serviceable forms is at times chaotic, and the quest for what Thomas Troeger calls a "disciplined creativity" does not always proceed in linear fashion. ${ }^{51}$ Even as I consult with the Muse of Realization and attempt to embody my inspiration, I do a lot of stopping and starting and crumpling up and throwing away old drafts...

There are some things that I will give you in this course that are taught. There are other things that are caught. Ultimately, art is caught. In every class in this course, there will be some science and some art. You are responsible for grasping both of them, but your means of grasping may be decidedly different in each case. For example in this lecture, or badly camouflaged sermon, I am preaching. I am trying to demonstrate some art to you so that you might reach up and catch it $[\ldots .$.

As we talk with God and with each other in this course, the air will be rich with scripture and poetic images, and after while you will have to reach up and get some of it by God's grace. At first, as you live into your vocation as a preacher and practice the art of sanctified persuasion, your tongue may get tangled a bit, but after while the Spirit will straighten your tongue. Or, as the African American slaves would say, if you work at this craft long enough and are obedient, God might just "cut loose your stammering tongue." 52 At first, you might cower at the thought of standing before God's people, but after while, God will put steel in your spine so that you might boldly do the work of an evangelist [...]

In this example, the boundaries between teaching and preaching are purposefully blurry. How do I understand the teaching elements of this portion of that lecture? First, I am communicating something about the power of images. As Charles Bartow suggests, homileticians must remind preachers and others scholars that "images" are not intellectually inferior to "concepts." ${ }^{33}$ Notice the barrage of images in the lecture: science, art, pulpit, megachurch, storefront, Nairobi, Nashville, songwriter, painter, poet, Muses, crumpled paper, grasping, camouflage, tongues, and steel.

50 Thomas H. Troeger, Preaching While the Church Is Under Reconstruction. The Visionary Role of Preachers in a Fragmented World, Nashville (Abingdon Press) 1999, 45.

51 Ibid.

52 This is a reference to a quotation in the African American slave narratives. See: Dwight N. Hopkins/George Cummings, eds., Cut Loose Your Stammering Tongue. Black Theology in the Slave Narratives, Maryknoll, N.Y. (Orbis Books) 1991, v.

53 Charles L. Bartow, God's Human Speech. A Practical Theology of Proclamation, Grand Rapids (William B. Eerdmans Publishing Company) 1997, 72-75. 
Since images are part and parcel of the preacher's craft, I expose students to the tools of the craft on the first day of the course.

Second, in this portion of the lecture, I am teaching students about the "terms of engagement" in this discipline. In homiletics, intuition is as spiritually and intellectually rigorous as cognition. Unlike some other theological disciplines that thrive on the mastery of terms, dates, and theories, homiletics is as much about submission to divine mystery as it is about mastery of human method.

Third, in order to bolster the pedagogical effectiveness of my first lesson on images and intuition, I must also do some preaching. At its core, effective preaching is not simply the dissemination of information. Preaching is a peculiar speech act that creates the conditions for an authentic decision about God. When people make the right decision about God, the consequence is shalom, God's intended wholeness for the creation. As a homiletician, I cannot simply teach about images. I must preach about images and with images.

The late William A. Jones, Jr., renowned pastor of Bethany Baptist Church in Brooklyn, New York, once said in a sermon, "A great truth, poorly spoken - in dry, unfeeling, uncaring language - leaves the listener without the fire and flame of inspiration. But any truth that rides on wings of poetic cadence captures the mind and warms the heart." 54 If preachers are to know the power of images, I must allow God to breathe life into the images in my lectures through my spirited, sacred performance, even in the classroom. It would be both tragic and utterly ironic if students never saw their homiletics professor preach in class. I believe that lectures and books about preaching ought to do some preaching.

\section{Second Creative Tension: Is the Goal Passion or Precision?}

My response is "both/and." By passion, I mean two things. First, I understand pedagogical passion to be a highly contagious love for and excitement about an intellectual discipline. My abiding belief in the power of preaching is communicable, and I hope that those who study with me will contract a life-long commitment to preaching. Second, passion is also a mental disposition. The English word "passion" is related to the Greek verb paschō, which means "to suffer" or "to endure." Thus, in the context of teaching, passion is a mental willingness to endure vulnerability for the sake of student learning. If I want preachers to cultivate their capacities for vulnerability and risk in the pulpit, I must be willing to abandon a cold, pre-determined professorial tone and demonstrate a spiritual and emotional openness that intuits the vibe in the classroom at any time.

As crucial as passion is for effective teaching, passion by itself can easily lead to unenlightened zeal. Precision serves as a check on passion, preventing reckless endangerment in the classroom and in the pulpit. By precision, I mean studied attention to intricacies and an unswerving 
commitment to getting the details right. As I often tell my preaching students, cardiac surgical residents in the medical school do not advance in the curriculum or the profession by being "close enough" in surgical training. "Close enough" when operating on a heart might translate into a patient's death and a malpractice suit.

Is not the preacher in possession of a surgical instrument when she preaches? Hebrews 4:12 declares that the word of God is "sharper than any two-edged sword, piercing until it divides soul from spirit, joints from marrow." If physicians in the medical school must take an oath, should not physicians of the soul in the divinity school take a similar oath? When doctors of the soul enter into homiletic surgery with the living word of God, they, too, should utter the oath: Do no harm! While we must make room for the mysterious presence of the Holy Spirit that transforms all our pulpit work, preachers should minimize the potential for error and harm by their dedication to professional precision. When treading upon the holy ground of a pulpit, precision is the appropriate posture.

In addition to modeling passion in my own classroom practices, I offer students opportunities to explore the contours of their passion through classroom exercises. Of late, I have become very interested in the kinesthetic dimensions of preaching. If the gospel is truly good news, we should allow not only our mouths but also our entire bodies to share in its proclamation. Thus, I regularly encourage my preaching students to investigate ways that gestures and movement can aid, and at times even replace, the spoken word in a sermon.

To demonstrate the kinesthetic dimensions of preaching, which can emancipate preachers for passionate proclamation, I often will read a passage of scripture and randomly call students to the front of the classroom in order to interpret the passage with their bodies and without the aid of the spoken word. For instance, one semester I used the descriptive passage in Isaiah 12:3, "With joy you will draw water from the wells of salvation." I challenged the students to embody the joy of thirsty people drawing water from a generous well. Typically, many of my students are inhibited, even embarrassed, to allow their bodies to engage in passionate expression. The disdain for or at least discomfort with the body that is perpetuated by certain dominant, western intellectual and religious traditions has straight-jacketed many preachers, thereby robbing them of the communicative power of their bodies. ${ }^{55}$ In order to remove the straight jackets from my students, I often ask this question during that exercise

54 William A. Jones, Jr., God on the Left Hand, sermon preached at the Hampton Ministers Conference, Hampton, Va., 1986, cassette.

55 For an intriguing discussion of the role of bodies in worship from African and European orientations, see: Elochukwu E. Uzukwu, Worship as Body Language. Introduction to Christian Worship. An African Orientation, Collegeville, Minn. (The Liturgical Press) 1997, 1-40. 
and after their in-class sermons: How can your body get in on the good news? Liberating our bodies to assist in proclamation is risky business, but the potential homiletic dividends make such risks necessary to take.

In order to sensitize my students to the importance of precision, I regularly introduce them to "Braxton's stopwatch." For instance, one of the most challenging exercises in the course is the short story exercise. I give each student a complex short story about life in the southern United States. I then require them to re-tell the story to classmates in three minutes without the aid of notes. Their stories are timed with a stopwatch, and their grade depends both on how well they re-tell the story and on their ability to stay within the time frame. The pedagogical payoff is almost selfevident. The Bible is an inexhaustible piece of literature, and on a weekly basis preachers must learn how to select with precision the most relevant details to support their work. Far too many preachers flunk on Sundays because of imprecision. In attempting to do too much, many preachers actually accomplish very little in the pulpit. Thus, preachers need to know that often the little details make for the best and biggest sermons.

\section{Third Creative Tension:}

\section{Is the Emphasis Homiletics or Hermeneutics?}

My response is "both/and." Homileticians must negotiate the creative tension between homiletics and other theological disciplines such as biblical hermeneutics. On divinity school faculties, homileticians are called upon regularly to help students integrate the disparate elements of the theological curriculum. This is understandable since preaching integrates many theological disciplines and has implications for those disciplines. ${ }^{56}$

Walter Harrelson, the renowned biblical scholar, once spoke to me about the importance of theological integration in the homiletics classroom. Harrelson said, "In other classrooms in the divinity school, faculty take a dollar bill and turn it into change. In the homiletics classroom, your responsibility is to take change and turn it back into a dollar bill." 57 Theological education should facilitate the valuable work of analysis and deconstruction (turning a dollar bill into change). It also should facilitate the equally valuable process of synthesis and reconstruction (turning change into a dollar bill).

Students bring to the homiletics classroom valuable theological change. Yet, in its present form, some of this change can be unwieldy for the practices of professional religious leadership such as preaching. Thus, homileticians assist preachers in transforming this change into larger re-

56 Preaching depends upon and also influences theological disciplines such as biblical hermeneutics, church history, constructive/systematic theology, ethics, pastoral care, religious education, liturgics, and congregational studies.

57 Personal conversation, 12 October 1999. 
ligious truths that have greater "currency" - truths that can more easily circulate and enrich people's lives.

Let me now examine theological integration more explicitly in terms of the tension between homiletics and biblical hermeneutics. My understanding of the interdependent nature of these two disciplines has fostered my dialectical relationship to both disciplines. The African American homiletic tradition that has shaped me assumes that effective preaching is conversant with scripture. Consequently, in my vocational journey, the completion of a Ph.D. in biblical studies was a natural outgrowth of my love for preaching and my awareness of the Bible's importance in preaching. ${ }^{58}$

My training in Biblical hermeneutics has fostered in me a profound respect for ancient history and has reminded me that sermons never create a completely new sacred drama. There is a historic script: scripture. This script provides to preaching a historical grounding, even as it invites preachers to courageous improvisation in their biblical interpretation. Thus, I teach biblical hermeneutics to preachers as a call to humility. Contemporary preachers should handle these ancient texts in ways that respect the wisdom and experiences of our forbears in the faith. We should come to these texts mindful that we are not the first or most perceptive persons to grapple with God and to search for answers to life's most perplexing dilemmas.

Similarly, my homiletics training has instilled a yearning for contemporary relevance into my work in biblical studies. Many biblical scholars have increasingly recognized the narrowness in some traditional biblical scholarship. When the search for ancient biblical sources, sayings, and situations obscures the "sacred texture" of biblical texts, we neglect the fullness of scripture's religious and cultural power. ${ }^{59}$ The Bible certainly contains ancient history, but ancient history per se is not the Bible's ultimate subject. God is. Sacred claims about God and other religious realities form the heart of scripture's message.

Homiletics, a discipline very much at home with sacred claims, has empowered me to ask a pertinent question about the Bible and scholarship on the Bible: So what? Once the ancient sources have been sorted, the grammar has been parsed, and the social contexts of early Judaism and early Christianity have been reconstructed, so what? What did scripture's sacred claims mean to these ancient communities? How did these sacred claims impact daily life in these communities? Furthermore, homiletics has compelled me to ask the "So what?" question in an even more contemporary manner. The homiletician in me reminds the biblical scholar in me that ancient history is not the only history. The ancient meanings of

58 In my Ph.D. training, my primary area was New Testament studies and my secondary area was homiletics.

59 Vernon K. Robbins, Exploring the Texture of Texts. A Guide to Socio-Historical Interpretation, Valley Forge, Pa. (Trinity Press International) 1996, 120-131. 
a biblical text, to the degree that we can grasp them, never halt a text's interpretive trajectory. Biblical texts have living, ongoing histories and meanings, which guide the lives of millions of contemporary people.

My emphasis on the present, homiletic possibilities of scripture reflects my commitment to the African American homiletic tradition. Henry Mitchell insisted, "The best of black preachers do not merely use the Bible; they let the Bible use them. Their intuitively flexible approach to the Bible leads them to ask, 'In this passage of scripture, what is the Lord trying to tell me today?" 60 As a homiletician, I must therefore ask of biblical texts: So what? What difference do texts in Genesis make to the discussion of stem cell research? What difference do texts in Joshua and Judges make to the discussion of "just war" theories? What difference do Pauline texts make to the discussion of gender equality and the role of women in society? These are the questions homileticians raise and answer as they teach and preach.

Homiletics gives wings to biblical hermeneutics, encouraging ancient texts to make the long and necessary journey to the twenty-first century. Biblical hermeneutics provides historical grounding to homiletics, ensuring that creative leaps of imagination in the pulpit are faithful to historic traditions and are not just flights of fancy. My father, who was a seasoned Baptist pastor, often said to me, "Son, sometimes you will need wings to fly over a storm; and other times you will need roots to withstand a storm." In the creative tension between homiletics and biblical hermeneutics, I equip my students with wings and roots so they and the communities they serve can fly over or withstand the ferocious storms of cultural conflict, sickness, poverty, violence, and death.

\section{Conclusion}

Teaching preaching in a divinity school requires me to hold creative tensions in careful balance. If you ask me whether I, as a homiletician, should teach or preach, or whether the goal in training preachers is passion or precision, or whether in my classroom I should emphasize homiletics or hermeneutics, my response to these questions is: "All of the above!"

60 Henry H. Mitchell, Black Preaching. The Recovery of a Powerful Art, Nashville (Abingdon Press) 1990, 59 (emphasis added). 
Teaching Leadership and Administration: Pedagogy and Poetics

\section{Thomas Edward Frank}

The biggest problem with teaching leadership and administration courses in a school of theology is that nobody wants to take them. Perhaps that is hyperbole. Nonetheless, based on the looks on student faces the first day of class (bearing similarity to their arrival at a medical building for major dental work) and based on reading some years of student evaluations, at least at the beginning when they sign up, many students come to these courses grudgingly. They know that administration is part of what pastors, heads of religious non-profits, and program staff persons have to do. They know they have to manage an organization. They know that leadership is expected of them. The idea of spending a semester looking at financial reports and personnel manuals, however, is a distinct turn-off.

Because actually the biggest problem with teaching leadership and administration courses in a school of theology is that everybody already knows what they are. The subject matter is obvious. Just look at the proliferation of institutes and seminars, books, videos, and CDs announcing the secrets of effective leadership, the techniques of successful fundraising, the seven steps toward managing your time and your self. Everybody knows that church leadership and management is a growth industry These are the books seminarians probably buy more of when they graduate. Certainly the church models that will be lifted up before new pastors will be the congregations with the biggest, the most, and the best. Better to hop on the express train now while still in seminary than wait until clergy meetings listening to the buzz about best practices, branding, and benchmarking without any idea what dialect is being spoken. ${ }^{61}$

As a teacher, I step boldly into this onrushing wind of productivity and performance. I show financial campaign videos from "successful" churches and ask students to write down key words, visual images, sounds, and

61 Among the literally thousands of leadership books, those popular among many pastors, church executives, and seminary teachers include: John C. Maxwell, 21 Irrefutable Laws of Leadership, Nashville (Thomas Nelson) 1998; Stephen R. Covey, The Seven Habits of Highly Effective People, New York (Simon and Schuster) 1989; Oren Harari, The Leadership Secrets of Colin Powell. New York (McGraw-Hill) 2002; and Kenneth H. Blanchard/Bill Hybels/Phil Hodges, Leadership by the Book. Tools to Transform Your Workspace, New York (William Morrow) 1999. More substantive discussions that locate leadership in organizational and communal context include: Peter Senge, The Fifth Discipline. The Art and Practice of the Learning Organization, New York (Doubleday Currency) 1990; Joyce K. Fletcher, Disappearing Acts. Gender, Power, and Relational Practice at Work, Cambridge, Mass. (MIT Press) 1999; and Jim Collins, Good to Great. Why Some Companies Make the Leap and Others Don't, New York (HarperCollins) 2001. See also the following websites: Academy of Religious Leadership (www.arl-jrl. org), Alban Institute (www.alban.org), Congregational Resource Guide (www.congregationalresources.org), and Wharton Center for Leadership and Change Management (leadership.wharton.upenn.edu) (January 2008). 
gestures that communicate the character of the congregation portrayed. I bring up web sites, of which there are untold thousands, and challenge the students to find the sponsor, look carefully at the language, and assess the relationship between the assumptions about God and world on the site and those same assumptions in the faith tradition in which the student will serve. We talk about how relative it all is, how perspectives of gender, ethnicity, economic class, and social ideology shape what is considered to be "leadership." We muse about what administration means in a faith community of fifty participants meeting in a sanctuary built for a thousand. I urge them to tune up their critical antennae and ask good questions. The soaring balloons of inflated expectations start drifting back to earth.

Because actually the biggest problem with teaching leadership and administration courses in a school of theology is that nobody knows what they are. Leadership seems more a slogan than an identifiable phenomenon, at best an elusive practice that is almost completely relative to social context and situation. As for administration, is it anything more than the routines of producing documents and arranging meetings that produce more documents? 62

So as a teacher, I step boldly into the void, trying at least to make a start with them to construct leadership as a practice that is meaningful in the context of continuing Christian community. I offer a definition: Administration is the intentional bringing to focus of the gifts and resources of a community so that it can fulfill its vocation and purposes. The students dutifully write this down. I then spend about four weeks drawing them through lectures and readings into four interpretive frameworks or perspectival lenses for understanding churches as organizations: cultural (the symbols, language, rituals, stories, gestures, and habits that make a congregation peculiarly itself), familial (the emotional relationships and histories that shape informal authority in a congregation), political (the forms of power and authority, and the polity of arrangements for participation and action in governing the congregation), and productive (the systems through which congregations identify their primary tasks and achieve them in a continuous process of engagement). I like the format and have learned a lot from it myself. It bears similarity to the work of Lee Bolman and Terrence Deal, though they manage to popularize the frames as the Temple, the Family, the Jungle, and the Factory. ${ }^{63}$ So much

62 For further discussion of leadership and administration perspectives and literature, see: Thomas Edward Frank, The Discourse of Leadership and the Practice of Administration, in: Journal of Religious Leadership 1/1, spring 2002, 7-30; and Thomas Edward Frank, Leadership and Administration. An Emerging Field in Practical Theology, in: International Journal of Practical Theology 10/1, 2006, 113-36.

63 Lee G. Bolman/Terrence E. Deal, Reframing Organizations. Artistry, Choice, and Leadership, San Francisco (Jossey-Bass) ${ }^{3} 2003$. 
for my intellectually hard-wrought pedagogical scheme, but they have sold a lot of books by making it catchy.

Because actually the biggest problem with teaching leadership and administration in a school of theology is that most of the students have little or no clue what I am saying. They have glimmers, sometimes very bright insights, from previous work experience or from part-time work in a church while in school. Most of them, however, are not actually bearing the burdens of being a pastor, or carrying out the responsibilities of a full-time position in a church or non-profit. Even if they are not completely intimidated by the prospect, for most of them what I am saying is abstract, because if it means anything, it holds that meaning only in specific contexts. Unless we are all in some context, preferably a common context, we cannot even know what the questions are. If we cannot know even the questions, then all these answers run off us like rain off a window.

So as a teacher, I have tried to open up the snow dome of the classroom so we get a whiff of the air of real situations. I send the students out to observe church meetings and try to describe accurately what they saw, and to discern levels of reality about the situation through the four lenses of the course. Most interesting lately have been my invitations to pastors to write case studies out of their daily experience. We have heard everything from nearby businesses suing a church over relocation of the homeless ministry to their end of church's downtown block, to an African American pastor serving a predominantly African American congregation in a church building that used to be occupied by white folks, who tries to get the white morticians to stop burying people in the adjacent church cemetery without even notifying the church. We have had priceless moments when I invited the pastor-authors to come to class for the discussion of the case. There was the day the pastor stood up after the student presentation, thanked them, and said she hadn't even wanted to come today The case had been about her falling out with a former protégé over charges that her protégé's husband was sexually harassing church members. The pastor was unsure she wanted to attend any discussion of this case, but then thanked the students for a thoughtful presentation. You could have heard a pin drop. There was no way that the students could not think that the knotty issues of leadership and administration are real. So far so good, and I was relieved. The pastor could have been angry because the students were still analyzing, using the frameworks I had been trying to communicate. That can be great for students and rewarding for me as a teacher, but it fell short because they were still surprised by the pastor's pain, because they were not actually in the situation.

Because actually the biggest problem with teaching leadership and administration in a school of theology is that there is no way to get trial practice in these practices. If an ecclesial practice is some kind of regular action that is accompanied by theological reflection, embedded in a tra- 
dition of similar practices in other contexts and circulating through the continuing life of a community, then practicing such a practice is fully meaningful only in continuous actions in a context in a community. This is the point at which we practical theologians have so often overstated what reflection is. We are tempted to think of reflection as standing slightly outside the flow of events or on the periphery of situations, and the context of the classroom where our students are seems just the right venue for what we call "critical distance."

Practitioners have no liminality of that sort, however. When you are pastor, you carry the continuing life of this community of faith with you everywhere. There is no place to step outside the flowing stream. For a practitioner, reflection is more like a disciplined attention to what is going on and a deliberate processing of experience. Administrative leadership as a particular practice of Christian community is a continually deepening disposition of attending to the community as it interacts with its environment and nurturing the community toward the fullest realization of its gifts and resources. Such a disposition is not always conscious and certainly not always rational. The pastor-authors who come to my classes discover what they know by talking about the situations. They learn by explaining, and I think are sometimes amazed to realize what they know. As a result, the students at least get to see a more experienced professional learn, even if they do not fully realize what they are hearing. ${ }^{64}$

That is the reflection part. What about the theological part? The biggest problem with theological reflection in a leadership and administration class in a school of theology is that nobody wants to do it. Again, perhaps that is hyperbole. Yet few students come to my classroom imagining administration as an essential aspect of their vocation. It might be part of what makes their vocation possible, in the way that a functioning furnace creates a warm sanctuary that makes their preaching possible, but it is not what they are called to do. They are called to preach, to teach, to give pastoral counsel, to be advocates of social justice. If leadership means anything, it means this kind of public witness first. As for administration, it is only a necessity for making one's real vocation possible and therefore does not require that much theological reflection.

Because actually the biggest problem with theological reflection in a leadership and administration class in a school of theology is that everybody already knows what it is. Twenty years ago, I would begin this class with a short theology paper. I would ask students to write a brief discussion of a biblical image that informed their understanding of leadership and administration. It was a bad assignment. You cannot believe how many papers I got on Moses (or perhaps you could). After all, the story

64 For further discussion of these pastoral case studies, see: Thomas Edward Frank, Writing Cases in Leadership. An Occasion for Pastoral Reflection, in: Journal of Religious Leadership 2/2, fall 2003, 1-20. 
of Jethro coming to Moses, pointing out the long lines of people coming for counsel, noting that the task was too heavy and could not be done alone, so that finally the work is divided between them (Exod.18:13-26), is this not the basis for multiple staff ministries? Is not Moses the model of courageous leadership? If a congregation wants to build a new sanctuary, why not name the whole effort the "Nehemiah project"?

I quit that assignment. I knew that most of the books and training programs that students would come across in future years would use the Bible this same way, glibly chatting about being just like "the New Testament church" without any critical thinking, without considering why I want to identify myself with Moses in my ministries, without letting scripture pose any questions to my congregation about what on earth we think we're doing, or letting the communities of the Bible be a witness on their own terms, or acknowledging the chasm between contemporary assumptions about church in the wealthiest society in human history and the minority Christian communities of the Roman world.

Because actually the biggest problem with theological reflection in a class in leadership and administration in a school of theology is that no one knows what it is. The chasm is so great that it reduces us either to biblical sloganeering or to ignoring scripture altogether. As a teacher, therefore, I start trying to construct a vocabulary for students to use in naming the world. I talk with them about how critical naming is, that how we refer to something mirrors how we perceive it. I make a contrast between Native American names for mountains that capture the unique character of each peak, versus the European adventurers' naming of mountains after themselves. I talk about what a difference it makes to view a historic nineteenth century building as an albatross versus naming it as a resource for community ministries.

I then teach about what it means to name the world as gift, to realize the givenness of all the resources we have received as Christian communities, to frame our practices as disciplined responses of gratitude for what we have been given. I contrast that with the language of possession and consumption dominant in a commercial society. Then I frame the whole second half of the course around the logic of stewardship - oikonomia, the economy of God's gifts and our wise and just management of those gifts for the well-being of the whole household of earth. You get the idea, and sometimes the students do, too.

Because actually the biggest problem with theological reflection in a leadership and administration class in a school of theology is that the students actually know what I am saying but do not trust it. They do not trust that mere language can carry the freight of seeing the world. Doesn't theological reflection instead entail stepping outside the situation to find truths, perspectives, or resources that are untouched by ambiguity and can tell us what things mean? Shouldn't every situation be analyzed to uncover the theological consistency inherent in it? 
In Kathryn Tanner's phrase, this all-too-common approach projects "onto the object studied what [theology's] own procedures of investigation require - a coherent whole," using theological categories as a kind of taxonomy to analyze and reach conclusions about the truth of situations. I am trying to persuade my students, by contrast, that no language of terms and ideas with stable meanings unaffected by context is available to us. Who would want to use such language anyway? No hypothesis about what is happening in a situation is worth pursuing until it is "formed and tested in community," as Tanner put it. ${ }^{65}$ As one pastor commented in discussing the case studies for my course, we need to "fast" from the instrumental application of theological formulas to living situations and enrich our vocabulary of interpretation together. We need multiple discourses in order to grasp what is happening in a church or organization to which we might apply the terms leadership or administration. I am trying to persuade my students that language is a way of imagining the world, of seeing what is incarnate there in fleeting moments of an onrushing reality that does not stand still for analysis.

Because actually the biggest problem with theological reflection in a leadership and administration class in a school of theology is that in this dominant culture we are so unpracticed in language. We are immersed in commercial chatter that manipulates our desires on one side, and in didactic pronouncement that tells us what to think, feel, and do on the other. As a response to this, I read my students poetry. You read that correctly. In a leadership and administration class, I read poetry. "All day I work / with the linen of words / and the pins of punctuation," I read from Mary Oliver. 66 "Some words are open like a diamond / on glass windows ... some words live in my throat / breeding like adders ... some words bedevil me," I read from Audre Lord ${ }^{67}$ Good language makes room for the play of imagination; as Lawrence Raab writes about Vermeer's painting of a "Girl Asleep at a Table," in which the artist painted over the little portrait standing on her table, depicting instead a mirror: "It's better, I want Vermeer / to have decided, not to show that much. / Let her keep her dream to herself. / Let the light be our secret." 68

In harmony with one of my regular texts by our colleague Martha Ellen Stortz, I think the most important thing a leader does is offer people language. ${ }^{69}$ This does not mean filling all the space, explaining

65 Kathryn Tanner, Theories of Culture. A New Agenda for Theology, Minneapolis (Fortress Press) 1997, 72-79.

66 Mary Oliver, Work, in: White Pine. Poems and Prose Poems, San Diego (Harcourt Brace) 1994, 1.

67 Audre Lord, Coal, in: The Vintage Book of Contemporary American Poetry, ed. J. D. McClatchy, New York (Vintage Books) 1990, 413-414.

68 Lawrence Raab, Great Art, in: The Probable World, New York (Penguin) 2000, 2930.

69 Martha Ellen Stortz, PastorPower, Nashville (Abingdon Press) 1993, 20-28. 
everything, telling how to interpret every situation. Like poetry, leadership is evocative, renewing memories, refreshing images. And like poetry, leadership is provocative, sparking insights, stirring vision. In churches convinced that they are responsible for productivity and performance, poetry offers a witness that revelation is a gift, here to be received if we are watchful for eternity in a moment. I say to my students, each of you listen, in Mark Strand's words, for "a sound announcing itself as your own, a voice / That is yours ... And you think that perhaps you are not who you thought, that henceforth / any idea of yourself must include a body surrounding a song." ${ }^{70}$ I tell my students, listen for the song, and imagine this: It is your gift in the community of faith.

70 Mark Strand, A Suite of Appearances, in: Blizzard of One. Poems, New York (Alfred A. Knopf) 1998, 23. For further discussion of the use of poetry in teaching leadership, see: Thomas Edward Frank, We're Going to Read Poetry in This Class? in: Teaching Theology and Religion 8/1, January 2005, 47-50. 
Teaching Mission in the Theological Curriculum

Stephen Bevans, S.V.D.

Catholic Theological Union (CTU), the school at which I have taught for twenty years, has recently revised its curriculum in a way that holds integration, interdisciplinary teaching and learning, practical theology, and the church's mission as core values of theological education. In this new curriculum I teach a course in what is called the "Integrating Core" that reflects on the task of witnessing to and proclaiming the gospel as an essential part of the church's mission. In this essay, I will share how I think my experience of teaching this course could add constructively to wider discussions about pedagogies and practical theology. These reflections are divided into three parts. In the first, I outline the general shape of the M.Div. curriculum at CTU. In the second, I focus in on the shape of the "Integrating Core" of the Curriculum. In the third, I describe the content and the pedagogy of the course that I teach within that core, entitled "Witness and Proclamation: The God of Jesus Christ."

\section{A New Curriculum}

For several years before the inauguration of our new curriculum in September 2004, the CTU faculty dreamed of a curriculum that would help our students to better integrate the theoretical disciplines like biblical exegesis, systematic theology, ethics, and spirituality with the more practical disciplines like liturgical studies, preaching, and pastoral care. As we began in earnest in January 2003 to design such a new curriculum, we were struck by the fact that all our program outcomes could be summarized under four goals. We wanted to be a school that trained ministers who (1) had a clear sense of their ministerial identity, (2) not only knew theological content but how to do theology (that is, theological method), (3) recognized that all ministry today had to be aware of its cultural and interreligious context, and (4) were rooted in and bearers of the Christian tradition. This vision of integration and these four goals became the cornerstones of our new curriculum.

We decided that each of these four goals would be themes for what we called "Foundational Core Courses," to be taken by all M.Div. students, ordinarily within the first two semesters of the program. To insure integration, we further decided that each of these courses would be team taught by professors from two different disciplines, and that guest appearances by professors from other disciplines would be developed as well. The courses would be known by the acronym "P-A-R-T," with the names tied to each letter of that acronym: "Pastoral Practice: The Theology of Ministry" for P, "The Art of Theology: Theological Method" for A, "Religion in Context: Diversity in Dialogue" for R, and "Tradition: Sources through History" for T. 
Since these courses would be broad and general introductions to ministry, method, context, and history, a second set of four courses would be offered, also to be taken within the first two semesters of a student's time at CTU. These courses, called "Complementary Core Courses," would focus a bit more narrowly on particular disciplines related to the P-A-R-T courses. $P$ courses at this level might focus on communication skills for ministry or how to prepare a liturgy. A courses might be an introduction to systematic theology or methods of moral decision making. $\mathrm{R}$ courses might address ministry on the margins or an introduction to the three Abrahamic faiths (taught by a Christian, a Rabbi, and a Muslim theologian). The $\mathrm{T}$ courses, however, would always be an introduction to biblical studies.

A next level of courses, taken throughout the ensuing three years of the curriculum, were called "Integrating Core Courses." The idea of was that, although integration of pastoral practice, method, context, and tradition might be encouraged in all courses taught at CTU, these four courses would make a special effort at integration. I will expand my explanation about these courses in the next section.

The rest of the curriculum remained fairly standard. In a student's second year, she or he would participate in a ministry practicum connected with a weekly group theological reflection. There would be a number of "area requirements" in biblical studies, systematic theology, history, ethics, spirituality, liturgy, and cross-cultural studies. There would also be a number of electives. Toward the end of the student's study at CTU, he or she would participate in a one credit hour "capstone course" that would assess the level of integration that took place over the four years of theological study.

\section{The Integrating Core}

During the last three years in the M.Div. program, as I have mentioned, students were required to take four "Integrating Core Courses" in which the teacher would lead the students to integrate the elements of P-A$\mathrm{R}-\mathrm{T}$ around particular themes. The question for the design team was, however: What should be the themes? At first, we thought they could be doctrines from the creed, or sections of the Catechism of the Catholic Church, or major documents of the Second Vatican Council. The idea then surfaced that we might focus on elements that are constitutive of the church's mission. One course would focus on the element of witness and proclamation, and was entitled, "The God of Jesus Christ." A second course would study the element of justice, peace, and the integrity of creation, and was called, "Living the Values of the Reign of God." A third course would emphasize the elements of dialogue and inculturation, and was labeled, "Ministry Across Boundaries." A fourth course would focus on the element of liturgy, prayer, and contemplation, and 
was named, "Ecclesial Spirituality." Each course called for an integration of the theoretical and the practical, and each course was to emphasize at various times the ministerial implications of the subject matter, the methodological background in thinking about the theme, the contextual nature of the questions discussed, and the themes in tradition that the theme required to be understood.

\section{Teaching "The God of Jesus Christ"}

The course that I teach is the first one mentioned immediately above, "Witness and Proclamation: The God of Jesus Christ." The idea behind this course is to connect systematic theology with mission theology. What should motivate Christians to witness to and proclaim the gospel is their understanding of and excitement about the God of Jesus Christ. The goal of the course, therefore, is not just a deeper and more critical understanding of the God of Christians. It is also the motivation to be enthusiastic and faithful witnesses and proclaimers of the good news, that is, enthusiastic and faithful practice. Every class period emphasizes (and I point this out in the introduction to each class) one or more elements of P-A-R-T. For example, when Jesus' ministry (parables, miracles, inclusive behavior) is treated, I point out that we are focusing on A (method) in a critical reflection on the gospel narratives, and on $\mathrm{T}$ (tradition) in terms of the community's memory of Jesus of Nazareth.

In the first class, I speak of the criteria by which we can know that an idea or image of God is true or false, reflecting the true God or the worship of an idol. This is the articulation of what Rosemary Radford Ruether has called the "critical feminist principle," which I have widened and renamed the "critical creation principle." 71 In classes two and three, we then reflect on God as Holy Mystery, known and spoken about only in metaphorical or analogical language, but experienced by women and men as "inside out" in the warp and woof of history, in our deepest struggles and desires, as God's "Holy Spirit."72 In the next two classes we reflect how this Spirit takes on concreteness and a human face in Jesus of Nazareth, both in his ministry of mercy, challenge, healing, and inclusiveness, and in his facing the consequences of such a life by his death on the cross. In this way, God is revealed as calling women and men to a community that is forgiven and forgiving, as unambiguously involved in the pain of life and the liberation of people from evil, as vulnerable and yet triumphant in weakness on account of Jesus' being raised from the dead. This is Part I of the course.

71 Rosemary R. Ruether, Sexism and God-Talk. Toward a Feminist Theology, Boston (Beacon Press) ${ }^{2}$ 1993, 18-20.

72 Stephen Bevans, God Inside Out. Toward a Missionary Theology of the Holy Spirit, in: International Bulletin of Missionary Research 22/3, July 1998, 102-105. 
The next two classes (Part II) reflect on the full understanding of the God of Jesus Christ as Holy Mystery, Spirit, and Incarnate Word, dimly understood in the earliest Christian writings and gradually articulated under the pressures of heresy as a trinity of persons, calling humanity and even all creation to communion and friendship. The doctrine of the Trinity points to a way of seeing reality in terms of radical relationship. ${ }^{73}$ It is an icon of the just society to which Christians are committed, ${ }^{74}$ the foundation for interreligious dialogue as well as the foundation for efforts of inculturation. ${ }^{75}$

Having developed an understanding of the God of Jesus Christ as a God totally "for us," "76 whose cause is the cause of men and women, a God "concerned for humankind," 77 the next section of the course (Part III, which usually involves three classes) explores the understanding of God in the context of various cultures and world religions. I have had guest lecturers speak of God in a Latino/a context, an African American context, an Asian context, and in the context of Islam. Obviously the strong stress of this section is on the R (context) section of the P-A-R-T acronym. A final section of the course is devoted to the burning issue of the existence of evil, divine providence, and the doctrine of divine omnipotence. This section is developed in the context of several contemporary theologians' dialogue with contemporary physics and evolutionary science.

At the end of each part of the course, an entire class session is devoted to discussions in both small groups and then the group of the whole. Here the topic is always the same and focuses on the P aspect of P-A$\mathrm{R}-\mathrm{T}$ : "How would you preach what we've talked about in this part of the course? How might you employ it in a session of spiritual direction? How does it impact your own spirituality?"

I have a fairly standard way of teaching each class. I always try to begin the class with a prayer that is relevant to the material we will be reflecting on in that session. Then there is a roughly twenty minute discussion of the readings assigned for that week. I offer a number of readings each week from various cultural perspectives. I encourage the students

73 Elizabeth A. Johnson, She Who Is. The Mystery of God in Feminist Theological Discourse, New York (Crossroad) 1992, 191-223.

74 Leonardo Boff, Trinity, in: Mysterium Liberationis. Fundamental Concepts of Liberation Theology, ed. Ignacio Ellacuría/Jon Sobrino, Maryknoll, N.Y. (Orbis Books) 1993, 389-404.

75 Mark S. Heim, The Depth of the Riches. A Trinitarian Theology of Religious Ends, Grand Rapids (William B. Eerdmans Publishing Company) 2001; and Stephen Bevans, Inculturation and S.V.D. Mission. Theological Foundations, in: Verbum SVD 42/3, 2001, 259-281.

76 Catherine M. LaCugna, God For Us. The Trinity and Christian Life, San Francisco (Harper Collins) 1991.

77 Edward Schillebeeckx, Church. The Human Story of God, New York (Crossroad) 1990, 114. 
to read all of the readings, but they only are obliged to read one, and to provide me with a 150 word summary of the reading. In the discussion, students who have read one reading help introduce it to others, and often the discussion leads naturally into the next part, which is a presentation that I give. I always use PowerPoint and try to present a good number of images (often unconventional) of Holy Mystery, the Spirit or Jesus, or of the Trinity as such. I am always open for discussion, and often an important discussion takes us away from my prepared presentation. In the discussion classes that take place after each part or unit, I have students discuss in small groups for the first hour, and then I process the discussions in the group of the whole for the next hour or so.

Besides the one summary of an article each week, students are required to read Elizabeth Johnson's She Who Is, a book that challenges many of the students who come from cultures where feminist concerns are not very strong and patriarchy is alive and well. This past year I also gave a final assignment in which $I$ encouraged the students to do something that tried to integrate the themes and ideas that we dealt with in class. The students have been really creative here. Some wrote reflection papers, some wrote homilies, some recorded homilies, some made PowerPoint presentations, some painted pictures, some decided to come to my office and just share with me what they had learned. In any case, I think that this was a course with a strong systematic theological content that moved beyond intellectual knowledge to reflections in more "practical" areas like homiletics, pastoral theology, communications skills, and aesthetics.

What were some of the pedagogical problems that I encountered? I think one of the most difficult problems was how to lead the students away from preconceived notions of God, particularly the presumption of speaking about God in male images. Young men, particularly those from Asian, African, and Latino/a cultures, have been very reluctant to move beyond their comfort zone. This was also true, however, for three African American women in the class, particularly one who was a Pentecostal. There was also always the "elephant in the room," that the Roman Catholic Church has strict rules about liturgical language and will not give women a truly participative role in church life and decision making. This "reality factor" created a genuine problem.

A second problem was getting people to talk in class discussions. This was particularly difficult for students from non-U.S. cultures where pedagogy is seen much more in terms of students being quiet and accepting before an all-knowing teacher. It was often the case that articulate, mature women and men would so dominate the discussion that younger students from other cultures could become passive. There were some moments of almost embarrassing silence in the class when I would ask a question like "Well, what have you learned from your readings this week? Anything excite you? Anything challenge you?" It was interesting, however, to see on the evaluations of the course that practically all the students did enjoy 
the class discussions. I was truly amazed, and realized that even though they may not have participated, they were listening and involved. Various students obviously have diverse learning styles, and different cultures have different ways of participation.

Third, it is hard to get students thinking across disciplines, let alone to get them thinking both pastorally and theologically. Working with them in large class discussions took every ounce of creativity that I had. Every once in a while, though, things did click, and as every teacher knows, this is what makes it all worthwhile.

\section{Conclusion}

I hope that these necessarily brief reflections have given a glimpse of our efforts at CTU, as well as my own personal efforts, to bridge the gap between the theoretical and the practical disciplines in theology, and move toward a way of conceiving and teaching theology that is infused with the vision that practical theology has developed over the last quarter century. My further hope is that there will come a day when the pastoral and the practical will not be relegated to separate disciplines, but will be the way in which all theology is conceived and all theology is taught. 
Pedagogy in Practical Theology: Examining Six Sub-Disciplines

Kathleen Cahalan, Carol Lakey Hess, and Bonnie Miller-McLemore

Questions about practical theology's role, as embodied in concrete practices within the classroom, stood at the heart of the spring 2006 biennial meeting of the Association of Practical Theology (APT). After several decades of concentrated reflection on the definitions and methods of the field of practical theology, it was time to ask fresh questions about pedagogy: How do those who teach in practical theology approach their subject matter? What is distinctive about pedagogy in practical theology and what might those who teach have to contribute to understandings of the field, theological education, and theological knowledge as a whole? We suspected that something new could be learned about practical theology by shifting our attention from theoretical investigation to our own practices or the study of what people actually do in the classroom and why they do it. We were not disappointed. We discovered that practical theologians are developing approaches that not only mirror the movement of practical theology beyond a remote corner of the curriculum and church but also point the way toward new conceptualizations of knowledge.

Panel presentations from six areas (education, worship, pastoral care, homiletics, leadership, and social mission) explored distinctive pedagogies, problems, and broader connections to practical theology as a field. These presentations appear as the foregoing six essays. Our goal in this article is to glean commonalties, identify differences, and name questions for further teaching and research that are raised by these essays. While the essays suggest how to teach specific subjects, more significantly they tell us a great deal about the field as a whole. ${ }^{78}$

\section{Commonalities}

Commonalties cluster around four interrelated pursuits: cultivating distinctive modes of knowing, engaging the body, forming persons for practice, and making space for God. Simply put, practical theological knowledge involves practice, embodiment, self-reflection, and recognition of God's presence. None of these characteristics are exclusive to the practical theology classroom, but all of them are particularly and sometimes powerfully present there, as each essay testifies.

78 For further reflection on the question of what can be learned about practical theology and, more generally, about theological education from teaching in the field, see: Bonnie J. Miller-McLemore, Practical Theology and Pedagogy. Embodying Theological Know-How, in: For Life Abundant. Practical Theology, Theological Education, and Christian Ministry, ed. Dorothy C. Bass/Craig Dykstra, Grand Rapids (Eerdmans) 2008, 170-190. 


\subsection{Modes of Knowing}

Teaching in practical theology challenges conventional academic assumptions about theological knowledge. Intellectual, conceptual, and textual knowledge, while important, does not suffice. Practical theologians use a variety of words to try to capture the knowing toward which they strive: emotional, psychospiritual, experiential, affective, intuitive, kinesthetic, and focused on images rather than only concepts. Such knowing might also be described as "activist." The aim, as John Witvliet suggests, is not simply to think about worship but to practice it more profoundly. Students in a class on mission must not just understand the God of Christianity, as Stephen Bevans says, but "be enthusiastic and faithful witnesses and proclaimers of the good news, that is, enthusiastic and faithful practice."

Some say such practical knowledge is improvisational. Others say it is chaotic, messy, ambiguous, concrete, tangible, and quotidian. Whatever words they use, there is general agreement that, as Thomas Frank asserts, "no language...with stable meanings unaffected by context is available to us." Sometimes expert practitioners do not know what they know until they have to try to talk about it. This does not make it less "rigorous" than cognition, however, as Brad Braxton argues. Knowledge rests on a "repertoire" (Katherine Turpin's word) rather than a systematic distillation of truth. It requires a "capacity for vulnerability and risk" rather than certainty. It even exposes people to "impenetrable" suffering, as Kathleen Greider suggests. Students may not really want to learn this kind of hardwon practical knowledge that they initially assume they already know or that they thought they would find so much easier to master than biblical or historical material.

This redefinition of knowledge has several implications. Almost all the essays use the term "real" life and directional words like "in" and "out" to describe the subject matter. Meaning only lies "in specific contexts," a location that confounds teaching inevitably abstracted from this. Students must go "out" of the classroom, whether imaginatively through dramatic exercises or literally through ethnographic research that allows a "whiff" of the "air of real situations." Knowledge depends on a practiced ability to "read" these situations and the cultural context around them. It comes from "loving" or "disciplined" attention to the multiple meanings of "what is going on."

Teachers use a variety of methods to cultivate such knowledge. They read poetry and autobiography, show films, analyze church websites, put people in small groups, and model the practice. They require students to evaluate their peers' practice, interpret scripture with their bodies, trace oral history, and assume prayer postures. Students write in first-person and teachers have to grade subjective exercises. All this comes into direct conflict with traditional knowledge and methods in many other classrooms. 


\subsection{The Body}

This "doing" of theology is not the same as "thinking theologically." It requires embodiment. Turpin says it involves "firsthand" or "hands-on" experience, terms that themselves point to the body. Practical knowing includes gestures, techniques, and skills (Turpin likens this to doing "scales" as part of learning to sing or play an instrument). Such actions are not something to be implemented mechanically or superficially. Instead, they are exercised with the hope that they will pave the way for rich understanding and engagement. In preaching, Braxton argues, the "manuscript is simply a transcript for an embodied performance." So also in other areas or perhaps even more so in areas like pastoral care and education: efforts at preparation are simply guidelines to embodied performance. What is taught must be embodied and not just anywhere but in this situation.

\subsection{The Importance of Person and Formation}

Disciplined reflection on oneself as practitioner is, Turpin asserts, a "signature element of pedagogy across the disciplines of practical theology." The other essays confirm this. Several essays portray the prior experience with which persons enter into learning about practices as both "liability" and "resource." Teachers must take account of a student's formation in a practice over time, just as that student must someday do the same as they work with others. Students are caught "midstream" between a past that may either foreclose or spark further knowing and a future that will involve trying to understand the malformation and creative transformation of others. In short, one must gain a facility in processing personal and communal experience. Only careful self-scrutiny nurtures this spirituality of teaching, or a related self-awareness or spirituality of preaching, caring, leading, praising, serving, and so forth.

\subsection{Knowing God}

Claims about practical knowing, the body, and the person all point to common assumptions about theological knowing. In rather mundane terms, one must become practiced in seeing and hearing theological language in real situations, whether about human nature, the cross, or eucharist. God appears in efforts to "assess what constitutes inappropriate or inadequate theological claims... with respect and compassion," to borrow Greider's words. Teachers suggest rubrics, categories, and questions to help people learn how to unearth the rich texture of lived theology and avoid "glib" use of scripture or doctrine.

God also appears more mysteriously as a presence in the room. Minimally the classroom itself must embody the "virtues" it espouses, whether empathic listening, proclamation, or witnessing. A worship class must be 
worshipful, a pastoral care class must demonstrate care, and so forth. Behind all these practices, therefore, are claims about the nature of God. Insofar as practical theological teachers succeed, they point toward the mystery of God's activity in human life, an outcome that necessarily rests on the gift of grace, as one essay plainly remarks.

Recognition of God's presence also comes simply and less mysteriously through moments of classroom doxology and a general ethos of gratitude. Theology is, as Frank says so well, a "way of imagining the world, of seeing what is incarnate there in fleeting moments of an onrushing reality that does not stand still for analysis." At some point, practitioners and those who teach them must shift from analysis to proclamation.

\section{Distinctions}

The four commonalities identified above show us that the sub-disciplines of practical theology share multiple ways of learning, knowing, and teaching. There are some distinctions and differences among the areas that can be identified, which point to the particularities of their subject matters. These differences exist mostly on a continuum and are not differences in kind. Differences can be identified in relationship to three issues: pedagogies of performance, the main "text" of the sub-discipline, and issues related to student experience and resistance.

\subsection{Pedagogies of Performance}

Practical theologians teach students how to do something: to preach, preside, offer care, administer, teach, or evangelize. In each case, pedagogies vary by the degree to which the practice can actually take place in the classroom, for both teachers and students. In the case of religious education and preaching, students are required to teach or preach in the class, as well as outside the classroom, and they learn from both observing others and engaging the practice themselves. In a worship class, students are given opportunities to lead some aspect of worship in front of the class, though probably not an entire service.

It is also the case that teachers teach the practice by doing it, and here the areas differ significantly from one another. Of course, religious educators never disengage from the practice they teach: students are observing them in the practice of teaching in every class period. Braxton notes how important it is for him to preach as well as teach, so that the very spirit and passion of preaching might be "caught" by students. Witvliet can also demonstrate how to do certain aspects of presiding and students can watch and learn. Tom Frank points out, however, this is more difficult in a course on administration. Students are not doing leadership and administration in the course, and there is not much for them to "practice" in front of others. The work of administration in all its various aspects 
is much harder to simulate in the classroom than preaching or teaching. Pastoral care is similar in the sense that introductory courses do not allow students to do counseling, nor is the teacher in the role of counselor in relationship to the students. Even so, Greider notes that students are quite attuned to the teacher's capacity for empathetic listening and capacity for care in relationship to the class. Students do learn an essential element of the practice of care from what the teacher is doing, even though they cannot enact the practice of care in its fullest expression.

\subsection{The Primary Text}

While as teachers, the six panelists do not aim to introduce students to their "discipline," there are ways in which the very nature of the discipline impacts teaching the subject matter. Greider is the most honest about the scope of pastoral care and the enormity of teaching about the "living human document" in all aspects of relationality, culture, and suffering. The topic seems without limits, which raises the question of whether there are any limits on the practice of care. Presiding, preaching, and even religious education to a large extent have more particular subject matters and ecclesial contexts in which students will carry them out. Here the congregation is more the aim of the practice. This is also the case with administration, though Frank admits that students and most faculties are not certain what constitutes the content of the subject matter. For Bevans, teaching mission through systematic theology requires students to grapple with what they want to claim about who God is and how God is related to the world.

\subsection{Students' Relationship to the Subject Matter}

Students come with varying degrees of experience in relationship to each area and its core practices, which impacts how teachers approach learning through experience. Although this is true for any subject area, in practical theological teaching previous experience includes actual engagement in formative personal habits and communal practices of faith. Sometimes these learned habits and practices are more intractable than declared beliefs and confessions of faith or ideas about church history, God, and scripture. Students have a great deal of experience with education as students. Most have been in some type of school for about seventeen years prior to the beginning of their formal theological education. Many come to that education with experience as teachers in churches. Some have probably led some aspect of worship, and perhaps have preached. In most cases, however, students have not had a great deal of experience in administering and leading a congregation, though they may bring such experience from other careers. Some students have received pastoral care, but probably have limited experience of giving care as a minister. 
In each case, teachers must use student experience differently. While worship professors need to be careful not to dismiss students' experience, religious education teachers can find that experience might block student learning. In administration courses, Frank must bring in experienced pastors to help students get close to the subject matter. Before even considering how to evangelize, Bevans must get students to grapple with their tightly-held assumptions about God. Braxton must help students embrace the creative tension in preaching, and not try to tackle it as a problem to be solved.

All teachers face resistance to learning from students, but resistance varies in relationship to each area. Practical theologians can often face attitudes such as, "I already know this" or "This is not that important to study; I can pick it up later." Students are nearly always convinced that courses in administration are not worth their time in seminary, though they know they will face these issues in the ministry. In pastoral care, Greider remarks how shocked students can be to discover that knowledge about suffering and misery, whether of others or themselves, is often too much to accept. In preaching, and most likely teaching and presiding, students must face their anxieties about public performance, failure, and critique. Whether students think the subject matter is not important or too emotionally difficult, their capacity to learn through the resistance and struggle is often key to mastering a dimension of the practice and the self in relationship to the practice.

\section{Lingering Questions}

We asked about the pedagogies of practical theology and we generated several thick descriptions of what happens when the sub-disciplines of practical theology are taught. We have before us several different practical theology "ecologies," or interconnections between theology, theory, participation, cultural analysis, and technique (to name many of the essential aspects of practical theology).

These qualitative descriptions have helped us become what Elliot Eisner calls "educational critics" or "connoisseurs." educational criticism to "aesthetic criticism." The educational critic has a passion and a sense for good educational process and for critical educational questions. She or he knows how to look. The task of the educational connoisseur is to appreciate and render "what is there." Therefore, at the heart of educational criticism is disclosure. The educational connoisseur is a "midwife to perception." 80 We note two dynamic tensions that have been "rendered" for us when observing excellent practices of teaching practical theology.

79 Elliot W. Eisner, The Educational Imagination. On the Design and Evaluation of School Programs, Upper Saddle River, N.J. (Prentice Hall) ${ }^{3} 1994,212-249$.

80 Ibid., 213. 


\subsection{Coherence and reconstruction}

Each of these professors stands within a certain history of the teaching of her or his discipline. Several of the essays rendered a sense of the sometimes fragile equilibrium between the teacher's place within the history of the teaching of her or his practice, and the destabilization or reconstruction of that practice in widening contexts. For instance, Greider describes her place within a pedagogical tradition that emphasizes a more western notion of self-reflection. While feminist understandings of self-in-relation have increased our sense of what is involved in selfreflection, can an eastern understanding of "no self" be accommodated? Alternatively, does this require a shift that reconstructs what is currently taught as pastoral care?

Because these sub-disciplines are highly sensitive to context, the coherence of the pedagogy can be in a constant state of disorientation. Teachers will respond to this dynamic differently, but the question before us remains: What is the relationship between the coherence of the teaching of practice and the openness of that practice to its ever-changing context?

\subsection{Wisdom and Analysis}

The second dynamic to notice is that between wisdom gained in the midst of practice (and participation) and the analysis that emerges from distanced reflection. The language used by Catholic Theological Union, as described by Bevans, gets at this dynamic (see the " $A$ " aspect of the curriculum: "The Art of Theology: Theological Method"). In preparation for the APT biennial meeting, we asked the panelists about the distinctive pedagogies in each of the sub-disciplines that define practical theology. The essays resulting from their presentations give several renderings of pedagogies of practical theology. We might well explore in the future what a practical theology of pedagogy would look like. Put another way, what are the implicit and explicit methods and theories of practical theology that ground and guide these pedagogies? For example, we know that these practical theologies of pedagogy take context seriously, if not as a starting point at least as an essential movement. We also know that these practical theologies often begin with practice and are concerned about a rich understanding of "application" (both in a hermeneutical and a functional sense). Yet such observations raise further questions of theory and method in pedagogy still to be explored, such as how theology informs pedagogy. Is there a process for engaging the "ecology" of elements, or is pedagogy more art and wisdom?

These general observations have highlighted some of the significant learnings about theological education and the discipline of practical theology gleaned from explicitly attending to pedagogical practices. We close these remarks by returning to Eisner's notion of educational aesthetics. The educational critic has a passion and even a "taste" for good educa- 
tion. She or he has observed, participated in, and reflected on education long enough to develop a "sense" for the elements of good education. These essays show a sense for good education. True, they are self-renderings, and as such they are "criticism in medias res." Yet perhaps that is another distinctive aspect of teaching practical theology. It is theology and art being judged while it is being practiced.

\begin{abstract}
In April 2006, the Association of Practical Theology (APT) in the United States hosted its biennial meeting at Vanderbilt University under the title, "Practical Theology and Its Sub-Disciplines: Pedagogies and Their Implications for Practical Theology." Panel presentations from six areas (education, worship, pastoral care, homiletics, leadership, and social mission) explored the distinctive character of teaching in each sub-discipline, what they hold in common with other fields, and broader connections to practical theology as a whole. Those six presentations are the central essays of this article. A brief, jointly-authored essay introduces the situation and themes of the APT meeting, while a concluding essay by the same group of authors names the commonalities and differences among the sub-disciplines, as well as questions for further teaching and research raised by this collection of essays.
\end{abstract}

\title{
Zusammenfassung
}

Im April 2006 fand an der Vanderbilt University der im Abstand von zwei Jahren regelmäßig stattfindende Kongress der US-amerikanischen Association of Practical Theology (APT) unter dem Thema „Praktische Theologie und ihre Subdisziplinen: Pädagogik und ihre Folgen für die Praktische Theologie" statt. Plenumsvorträge aus sechs Disziplinen (Religionspädagogik, Liturgik, Poimenik, Homiletik, Pastoraltheologie/Kybernetik sowie Diakonie) ergründeten den spezifischen Charakter der Lehre in jeder dieser Disziplinen, die Gemeinsamkeiten mit anderen Bereichen ebenso wie die grundsätzlichen Verbindungen zur Praktischen Theologie als Ganzer. Diese sechs Vorträge stellen den zentralen Teil dieses Beitrags dar. Ein kurzer, gemeinsam verfasster Abschnitt führt in die Situation und die Themen des APT-Kongresses ein, während ein abschließender Abschnitt derselben Autorengemeinschaft die Gemeinsamkeiten und Unterschiede innerhalb der Subdisziplinen benennt und Perspektiven für die zukünftige Lehre und Forschung herausarbeitet, die durch diese Aufsätze eröffnet werden. 